\title{
ADDITIONAL NOTES ON THE GENUS VERBENA. XXV
}

Harold N. Moldenke

VERBENA HAIEI SmaII

Additional synonyur: Verbena halif Small ex Moldenke, Phytologia $36: 47$, in syn. 1977 .

Additional \& emended bibliography: Loes., Verh. Bot. Ver. Brand. 538 74. 1912; G. W. Thomas, Tex. P1. Ecolog. Summ. 78. 1969; Bolkh., Orif, Matrej., \& Zakhar., Chrom, Numb. Flow. PI., Imp. 1, 71 (1969) and imp. 2, 717. 1974; [Bard], Bull. Torrey Bot. Club 102: 431. 1975 ; E. H. Jordan, Checklist Organ PIpe Cact. Nat1. Yon. 7. 1975; Moldenke, Phytolog1a 30: 142-143 \& 159 (1975) and 31 : 375, 377, \& 378. 1975; Perkins, Estes, \& Thorp, Bull. Torrey Bot. Club 102: 194-198. 1975; Anon., B101. Abstr. 61: 1C1.732. 1976; Hurd \& Iindl., Smithson. Contrib. 2001. 220: 10. 1976 ; Ziegler \& Sohmer, Contrib. Herb. Unfv. W1sc. LaCrosse 13: 16. 1976 ; Moldenke,

Phytologia 34: 20, 250, 251, 270, \& 279 (1976) and 36: 47, 128, $134,135,143,152$, \& 157. 1977; A. I. Moldenke, Phytolog1a 36 : 87. 1977.

Lewis and his associates encountered this plant along a streamside in Coahuila. Demaree reports it as "common" on lon ridges, at 670 feet altitude, in Texas. The Ellisons assert that it was "abundant in local population in full sun in sandy soil with V. brasiliensis, no hobridization evident", the corolla "bluishlavender".

Other recent collectors refer to this plant as an upright perennial herb, 2 feet tall, and have encountered it in old rice flelds, In sancty soil along roadsides, in open dry gravelly soils on rail road embankments, in "nearly level stiff or buckshot soils", on the river side of levees, In sandy dry open areas, and in "nearly level to gently sloping front lands", at 375 meters altitude. Brown refers to it as common on road shoulders in marshes NIIen found it abundant in open areas with $V$. temuisecta and Gmodon; Montz reports it infrequent on leves spIIIways with Ambrosia; and Bougere found 1t "not abundant, In amall compact patches on roadsides". A jour found it "abundant in very dry soil in shade with a lot of sedges and grasses".

The corollas are sald to have been "deep-blue" on $\Delta$ jour 11 , "Iavender" on Bougere 1087, Correll \& Johnston 22127, and Iuke 8.n., "blue" on N11en 675 \& 990, and Correll \& CorreII 12421, "purple" on Curry, Martin, \& N1en 437, and "purple to Iavender" on Killmer 35. Wendt and his associates found it growing "In sam Iine and probsbly sppsiferous fine alluvial soll in matorral desertico inerme $\mathrm{J}$ con espinos laterales with flne mineralized alluvial soil in bajada", growing with Prosopis glandulosa, KooberInia gpinosa, Condal1a, Ircine, and Selinocarpus. Eger reports It common "In full sun in sandy soll of pine woods with Oxalis, Aster, and Lobelia". Higgins found it among "mixed grassland 
shrubs with mesquite and oak predominating".

Brown \& McFarlin note that there are "no appendages on the anthers". Mrs. Jordan (1975) calls the specles "Hale's vervainn. Perkins and his associates (1975) Inform us that $V_{0}$ hale 18 highly autogamous (like V. urticifolia), the number, frequency, and pollen-carrying ability of Insect vectors favor crosses of $\mathrm{V}$. stricta Vent. with V. urticifolia L. and V. hale1. They found that 12 plants of V. hale1 which were insect-visited and with 462 potential seeds had a 68 percent seed-set, while 15 bagged plants with only 391 potential seeds had a 54.5 percent seed-set. They found that the anthers and stigmas in V. hale 1 are less than $1 \mathrm{~mm}$. apart and the corolla-tube is straight, the plants are short (25$70 \mathrm{~cm}$. tall) w1th an 1nflorescence of $10-58$ branches (mean 26.4), each with only 2 flower about $3.4 \mathrm{~mm}$. apart at anthesis, and observed the following insects visiting the flowersi Diptera: Nllograpta sp., Baccha sp. (with Verbena pollen on head), Systropus 8p. (with pollen or head), and V111a sp.; Hymenoptera: Calliopsis andrentfornis, Ceratina sp. (with pollen on head), Augochlorella striata, and Megachile sp. (wth pollen on head); and Lepldoptera: Hemlargus 1sola, Phycoldes phaon (with pollen on head), and Strymon mellmas.

Loesener (1912) c1tos Seler 3460 as "V. off1c1nalis L. forma?" from Atascosa County, Texas. The C. M. Allen 1179, distributed as $V_{0}$ hale1, is the type collection of $x \bar{V}_{0}$ allent Moldenke, while BIIIs, LeDoux, \& Fatkdns 964 10 V. canescens H.B.K.

Additional citations: SOUTH CAROLINA: Niken Co.: Rllson \& Bl11son 1010 (Sd-77488). GBORGIA: Sumter Co.s Moldenke \& Molden-

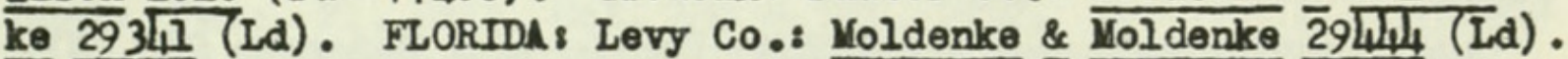
LOUISIAN : Acadia Par.: D. B. ml1s 58 (Lv) . Allen Par.8 Eger lll (Id). Bossier Par.: Robinette 147 (Lv), 203 (Lv). Calcasieu Par.: J. A. Churchtll s.n. [2 19y 1955] (Ln-20 4089); Wurzlow s.n. [Sept. 15, 1917] (Lv). Cameron Par.: C. A. Brown 9271 (Lv). East Baton Rouge Par.: C. A. Brom 1156 (Lv), .... [Apr1] 20, 1935] (Lv); Broin \& Morarlin 2118 (Mi); N. F. Petersen s.n. [May 7, 1909] (Lv, Lv). Jefferson Dav18 Par.: D. Dickinson s.n. [June 8, 1918] (Lv). Lafayette Par.: Claycomb s.n. [April 15, 1943] (Lv). Lincoln Par.: Thomas \& Grentll10n 2487 (KI-10265). Ouachita Par.: P1ckett \& Bot. Class 50 (Lo). Plaquemines Par.8 V. Keller s.n. [Aug. 24, 1917] (Lv, Lv). Pointe Coupee Par.3 M. Chanery $399 \overline{(L v)}$. Saint Charles Par.: Montz 3089 (Lv). Saint Helena Par.: C. M. 스len 675 (LV), 990 (LV). Saint Mary Par.: Bymum, Ingram, \& Javnes

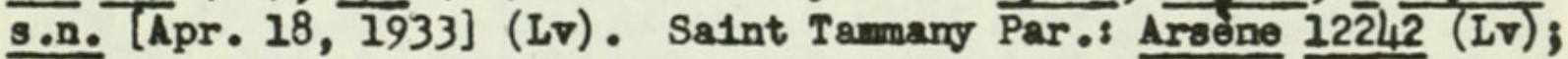
Bougere 1087 (Iv), 1096 (Lv). Tang1pahos Par.: Correll \& Correll 2254 (Lv). Terrebonne Par.s Wurzlow s.n. [May 1, 1912] (LV). Ver

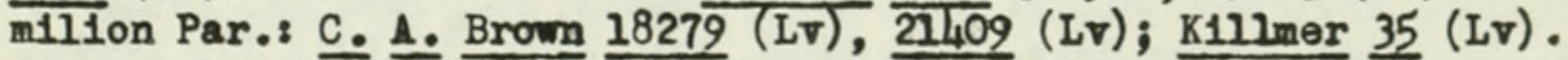
Vernon Par.8 Turba s.n. [April 22, 1935] (Lv). West Fellciana Par.: Curry, Martin, \& Allon 437 (LV). TBXAS: Austin Co.: Furzlow 
s.n. [1905] (Lv). Bowle Co.: Correll \& Correll 1242] (M1). Bra208 Co.s Ajour II (N). Cameron Co.8 R. Runyon 4857 (Hu). Comal

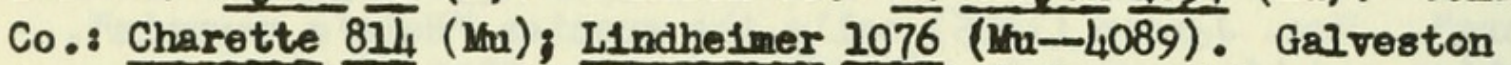
Co.: LIndhe1mer s.n. [Galveston, May 1843] (Mu-354). Harris Co.: Luke s.n. [2 Aprill 1972] (Lv). Orange Co.: J. A. Churchill 8. . $_{\text {. }}$ [1 May 1955] (In-204754). San Patric10 Co.8 R. Runyon 4720 (Iu). Tarrant Co.: Demaree 68284 (Ld). Wichite Co.s I. C. Higging 10022 (N). Young Co.: Correll \& Johnston 22127 (N). MXIICO: Coahulla: Lowis, Lehto, Keil, Neyer, LeBounty, \& Pinkava 5876 (Te-68563); Wendt, Ch1ang C., \& Johnston 10147 (Id). CULTIVATED: Missouri: Prince Paul of Thurttemberg 8.n. [Hort. Mergentheim] (Mu-1573).

VERBENA HALET f. PARVIFLORA Moldenke, Phytologia 34: 20. 1976.

B1bllography: Moldenke, Phytolog1a 34: 20 \& 251. 1976.

Citations: TEXAS: Galveston Island: Johnston, Johnston, Saustrup, Darr, \& Darr 12436a (Ac-1sotype, Z-type).

VERBENA HALET f. ROSEIFIORA (Benke) Moldenke

Additional bibliography: Moldenke, Photologiz $28: 213$ \& 362 . 1974 .

VERBENA HASSLERANA BrIq.

Additional bibliography: Moldenke, Photologia 30: 143. 1975.

Pedersen comments that this species is found in moist meadows, on the banks of small streams, and elsewhere in Corrientes. He found it in flower and fruit in Jamuary, and the corollas on Pedersen 988 are described as having been "lilac" in color when fresh.

Additional citations: ARGENTINA: Corrlentes: Pedersen 988 (N).

VERBENA HASSLERANA var. GLANDULOSA Moldenke

Additional bibliography: Moldenke, Phytologia $28: 351$ \& 464 . 1974 .

\section{VERBENA HASTATA I.}

Add1tional synoryug: Verbena pinnatifida $\mathrm{Ph} .0 x \mathrm{G}$. Don in Loud., Hort. Brit., ed. 1, 247. 1830. Verbens 1ac1niose Schwegr. ex Moldenke, Phytolog1a 34: 279, in syn. 1976. Verbena pan1culate L. ex Holdenke, Phytologia 3h: 279, in syn. 1976. Ver bena hastata var.paniculate Lam. ex Moldenke, Phytologla 34: 279, in 8 yn. 1976.

Additional \& emended bibliography: $G$. Don in Loud., Hort. Brit., ed. 1, 246 \& 247 (1830) and ed. 2, 246 \& 247. 1832; Loud., Hort. Brit., ed. 2, 552. 1832; G. Don in Ioud., Hort. Brit. ed. 3, 246 \& 247.1839 ; Buek, Gen. Spec. Syn. Candol 38 495. I858; Paine, Ann. Rep. Untv. N. Y. 18: [P1. Oneida Co.] 109. 1865; Kuntze, Rev. Cen. P1. 2: 510. 1891; Conard, PI. Iowa 4h. 1951; R. A. Davidson, State Univ. Iowr Stud. Nat. Hist. 20 (2): 77. 1959; Hall \& Thompson, Cranbrook Inst. Sc1. Bull. 39: 74. 1959; Cooper- 
rider, State Univ. Iow Stud. Nat. H1st. 20 (5): 70. 1962; P. W. . Thompson, Cranbrook Inst. Sc1. Bull. 52: 37. 1967; Barker, Univ. Kans. So1. Bull. 48: 571. 1969; G. W. Thomas, Tex. P1. Bcolog. Sumn. 78. 1969; Bolkh., Gr1f, Matvoj., \& Zakhar., Chrom. Numb. Flow. P1., Imp. 1, 717. 1969; Rimpler, Lloydia 33: 491. 1970; Scully, Treas. Am. Ind. Herbs 283. 1970; Anon., Bloresearch Ind. 7: 1061. 1971; Ellison, Kingsbury, \& Hyypio, Comm. Wild Fla. N. Y. [Cornell Ext. Bull. 990s] 19. 1973; Hatheway \& Ransey, Castanes 38 \& 77 . 1973; 1. \& C. Krochmal, Cuilde Ked1c. PI. U. S. 229-230, 246,257 , \& 258, f1g. 259. 1973; Bolkh., Grif, Katvej., \& Zakhar., Chrom. Numb. Flow. P1., imp. 2, 717. 1974; Bl-Gazzar, Egypt. Journ. Bot. 17 i 75 \& 78. 1974; R. D. Gibbs, Chemotax. Flow. P1. 3: 1753--1755 (1974) and 4: 2295. 1974; Mrs. P. Martin, Am. Horticultur1st 53 (5): 33. 1974; Roussean, G6ogr. Florist. Gub. [Trav. Doc. Cent. Stud. Nord 72] 376, 473, 502, 550, 643, \& 788, map 826. 1974; Stark, Am. Horticulturlst 53 (5): 11. 1974; Welsh, Utah P1., ed. 3, 354 \& 473. 1974; Whitney in Foley, Herbs Use \& Delight [198]' 1974; D. S. \& H. B. Correll, Aquat. \& Wotland PI. SW. U. S., 1mp. 2, 2 : 1396, [1398], 1399, \& 1775, f1g. 654 g-k. 1975; Koo1man, Act. Bot. Neerl. 24: 464. 1975; Moldenke, Phytologia 30: 143148 \& 174 (1975) and 31: 374, 376-378, \& 409. 1975; A. L. Yoldenke, Phytologia 32: 415. 1975; United Communications (Woodmere, N. Y.), Herbal Visual \& Study Chart n.p. 1975; H. D. W1ls., Vasc. PI. Holmes Co. Cat. 54. 1975; Grime, Bot. Black Amer. 191. 1976; Lacoursidre, Pontbriand, \& Dumas, Naturl. Canad. 103: 174. 1976; Moldenke, Phytologia 34: 247-251, 270, \& 279. 1976; Van Bruggen, Vasc. P1. S. Dak. 369 \& 536. 1976; [Voss], U1ch. Bot. 15: 237. 1976; Moldenke, Phytolog1a 36: 28, 29, 47, \& 126. 1977; F. H. Montgomery, Seeds \& Fruits 201, flg. 6, \& 230. 1977; Taylor \& Mac Bryde, Vasc. P1. Brit. Col. 436 \& 751. 1977.

Additional 1llustrations: Ellison, KIngsbury, \& Hyyp10, Comm. wild F1s. N. Y. [Cornell Ext. Bull. 990:] 19. 1973; A. \& C. Krochmal, Guide Medic. P1. U. S. 230, flg. 259. 1973; D. S. \& H. B. Correll, Aquat. \& Wetland P1. SW. O. S., imp. 2, 2: [1398], f1g. 654 g-k. 1975; F. H. Montgomery, Seeds \& Fruits 201, f1g. 6. 1977.

Montgomery (1977) describes the seeds of this specles as Mhutlets $2.0 \times 0.6 \times 0.5 \mathrm{~mm}$, simtlar to the previous species [V. bractesta], margins ridged, dorsal surface longltudinally 3-5ribbed on the lower half and reticulate near the apex, inner faces papillosen".

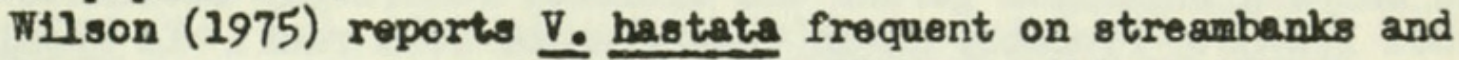
In low pastures and marshes in HoImes County, Ohio. Other recent collectors have found It on the shingle shores of lakes, in mack soll along drainage ditches, on prairles, by lakes with peat bogs along the shores, in meadows and ditches, on floodplains and open pond banks, in marshy land, and on gravel bars and rockg ground along oreeks.

The corolla is sald to have been "deep-purple" on W. D. Stevens 1633 and this collection also exhlbits perfectly hastate leaves. On Correll \& Correll 30034 the corolla was "lavender" and on Blake 
11178 1t was "vlolet-purple".

Hatharry \& Ransey (1973) record V. hastata from P1ttsylvania County, Virginia. Churchill \& Sutherland encountered it "in marshy banks of small pond depressions in cultivated fields with Salix, Cormus, Scirpus, and Asclepias in Otoe County, Nebraska. Thompson (1967) records it from Leelenau County, Michlgan, noting that it grows there "along roadsides and in meadows. Common"; Hall \& Thompson (1959) found it in Oakland County in the same state. Cooperrider (1962) reports it "frequent..... Marshy places; stream banks; wet ditches" in Clinton and Jones Counties, Iowa. Davidson (1959) says that it is common Musually in wet to molst open places, occesionally in upland woods and openings.....Plants of dry soil, not recognizable as hybrids, differ considerably from those found In moist situations, those from the dry places being smaller with less incised leaves and more sparingly branched inflorescences." This is a very valid comment and I have frequentiy observed these differences, too, anong others, in the fleld. I think that the dryland plants showing these characters deserve a form name.

Barker (1969) refers to $\nabla$. hastate as "Occasional, along prairle dralnage areas, in low prairie canyons, along margins of impoundments and streams. Occurs throughout the area [Kansas]." Stark (1974) asserts that it is usually found in "rich soils with high humus levels" and a pH level of 6.0, while Martin (1974) recommends it for "most open garden in sun with pH of $5-6.5^{n}$. Taylor \& MacBryde (1977) classify the corolla-color as "blue and violet" and gives its normal blooming period as June to September in British Columbia, where it is certainly var. scabra to which they are referring.

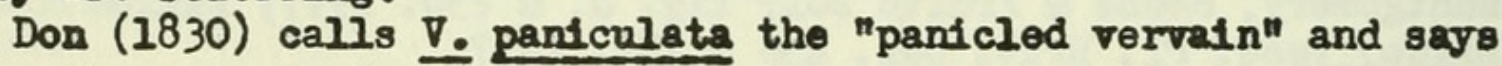
that it was introduced into English gardens from "N. Amer." in 1800; he calls V. hastata, which he keeps as a separate species, the "halberd-leaved vervain" and gives its date of introduction from "Canada" as 1710, while he says that what he calls V. pinnatifida, the "pinnatifid vervain", came from "N. Amer." in 1810. Curlously, he places V. pantculata in his section Indivisae and the other two in section Trifidee.

Verbena lacintoea is based on an unmubered collection from the Schwegrichen herbarium now deposited in the herbarium of the Staatssammlung at Munich. The plant was originally cultivated in the Leipsig botanical garden and exhibits remarkably laciniatelobed leaves. Probably it is deserving of form rank. It should also be noted here that very plainly hastate leaves are seen on the Herb. Schreber s.n. [Hort. Brl. 1770] \& s.n. [Insul. Bahamensis] specimens cited below, clearly showing why IInnaeus applied the epithet "hastata" to this species and also showing Farwell's reason for separating the cormonly found form of the species as var. paniculate. Personally, I feel that form rank would be more justified.

Rimpler (1970) reports the isolation of a new iridoid, hastatoside, from V. hastata. Gibbs (1974) reports that cyanogenesis 
1s absent in the shoots of this species, leucoanthocyanin is ab- . sent from the leaves, and syring in is absent from the stems, while the Ehrlich test gives negative results in the leaves and the Juglone test is negative in the stems and leaves but produces a blue fluorescence.

Scully (1970) reports that the Amerinds of North Amerlca used "vervain" in the trestment of colds and quite cormonly against dropsy, whth or without milkweed and decocted cottomwood leaves. Against faundice they used it as a decoction alone or with any of the following where arailable: c1nquefoil, parsley, oregon-grape, nettle-root, or columbine. Mixed with fat, 1t was used in treatIng swelling or hardening of the testioles, especially if acconpanted by pain. As an infusion for quieting the nerves, a sponge bath and tea of verbena leaves is still ueed today among same tribes; for scurvy an infusion alone or mixed with wormwood or birch leaves is used. It is drunk as a tea in cases of smallpox to mitigate the suffering; as a tea also for sore throat and intestinal worms, especially in children. But Scully points out that in almost all cases vervain was not the first choice of possible medications. It is probable that several species of the genus are involved here.

Material of V. hastata has been misidentified and distributed in various herbaria as "V. hasta I." On the other hand, the Bresinsky s.n. [Lafayette, 12.7.1967], Correll \& Correll 39844, G111key s.n. [July 31, 1945], Higgins 9712, KacDouga] 566, A. Ro Koldenke 1297, E. L. Roed 4034, Tharp 4504, Woodcox 55, and York \& Rodgers 363, distributed as typical v. hastate, actually represent var. scabra Moldenke, Herb. Zuccarin 8. . $_{0}$ [Hort. bot. Monac.] is a mixture of $x V$. baileyana Moldenke and V. officinalis L.; Chandrapanya 2 and $\underline{\text { Xirby } 160 \text { are }}$. brasiliensis Vell.; C. A. Brown B.n. [Sept. 30, 1936] is V. canadensis (L.) Britton; Engelmann s.n. [Banks of the Mississippi, July 1842] and Herb. Staatsherb. vilinch. s.n. [Hort. Bot. Yonac. 28.7.53] are xD. engelmannil Koldenke; Itts, Bell, Melchert, Patman, \& W1tt 12361 is xV. perriana Mol-

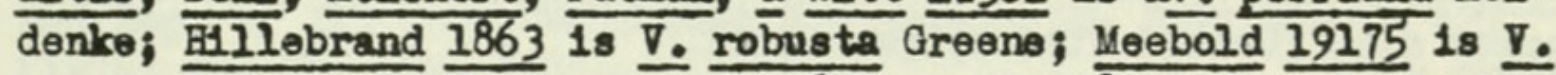
simplex Lehn.; Herb. Kumorr s.n. [K1ssissipp1] 1s V. urticifolia L.; and Schroer TI is V. xxtha Lohm.

Additional citations: MAIMB: York Co.: F. T. Hubbard $8 . n$. [VIII/15/1901] (Ld). VERMONT: Grand Isle Co.: Moldenke \& Moldenke 31103 (Ac, Ld). Lamo1lle Co.s Moldenke \& Moldenke $3100(\mathrm{Gz})$.

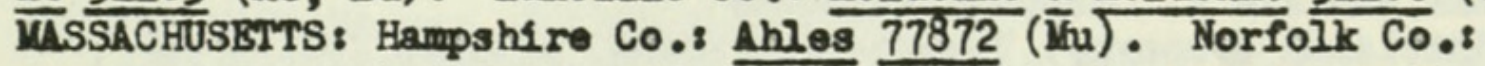
Blake 11178 (Ld). NITI YORK: Monroe Co.s H. Brnat 1102 (Mu). Oswөgo Co.: Moldenke \& Moldenke 31132 (Id). Schuyler Co.: J. A. Churahill 8.n. [23 Angust 1937] (In-213612); Moldenke \& Moldenke 3 III35 (Tu). Yates Co.: Moldenke \& Moldenke 31133 (Lv). NISTI JIRRSEY: Morris Co.s Moldenke \& Moldenke 25633 (Id, Id). County undetermineds Hillebrand s.n. (In). PENISYIVANIA: Berks Co.s Herb. Zuccarint s.n. [Reading] (Mu-321). Bucks Co.: Mayer s.n. [Qua- 
kertom, Aug. '76] (Mu). Iyconing Co.: Moldenke \& Moldenke 31149 (Mu, Ut). Monroe Co.s Swinerton s.n. [Pocono Mts., Aug. 1896] (Mu). Northampton Co.: Herb. Schreber s.n. [Bethlehen] (Mu-316), s.n. [Nazareth] (In-317). Tloga Co.: Moldenke \& Moldenke 31139 (T). Union Co.s Moldenke \& Moldenke 31250 (LV, Tu, T, Ws). County undetermined: Schweinitz s.n. (Mu--1257). IllinNOIS: Cass Co.s Geyer s.n. [Beardstown, July 1842] (14u-324, Mu-362, Mu--1676). Cook Co.3 Solereder o.n. [Chileago, Aug. 1893] (Ku-4lito). OHIO: Auglaize Co.: Purpus 242 (Mu). UICHICAN: Alger Co.: J. A. Churchill 9.n. [9 July 1964] (In-204262). Branch Co.: ㅍ. D. Stevens $1633(\mathrm{Ln}-237063)$. Ingham Co.: R. D. Bradbury $32(\mathrm{In}=161013)$. Lacomb Co.: J. A. Churchill s.n. [24 JulJ 1954)] (Ln--203431). Otsego Co.s Bresinskg 8.no [Bardwood Lake] (Mu). Wagno Co.: Far-

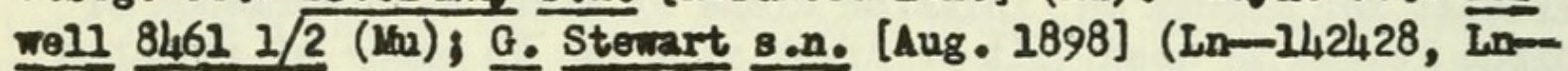
I42430). WISCONSIN: IaCrosse Co.2 Demaske 2220 (Id). IIINESSOTA: Hennopin Co.: Sandberg 152 [36] (Mn). KANSAS: Lyon Co.8 J. L. Watson I (LC). MISSOURI: Clark Co.: E. J. Palmer 43737 (Id). Salnt Louis: Eggert 7558 (Mu); Muhlenbsoch 1035 (Hu). County undetermined: Martens s.n. (Nu-322). NEBRASKA: Otoe Co.: Church111 \& Sutherland 3945 (N). OKLAHOMA: Muskoge日 Co.: Walles 7728 (Au-170667). Sequogah Co.s Wallis 5557 (Au-169341). TRXAS: Hemphill Co.s Correll \& Correll 30034 (Ld). CULTIVATED: Bahama Islands: Herb, Schreber s.n. [Insul. Bahamensis] (Mu-315). Englands Herb. Grim s.n. [H. Kew.] (Mu-314). France: Thouin s.n. [Hort. Par1s.] (1uu-355, Mu-356). Germans: Herb. Sohreber s.n. [Hort. Erl . 1770] (ku-319); Horb. Schwegrlehen 8. . . [Hort. Lipsiensis] (Yu-1365); Herb. Zuecarint 8.n. [h. b. B.] (Yu-359), s.n. [Hort. bot. Monac.] (Mu-357, Mu-358). LOCALITI OF COLUECTION UNDETERMINES: Herb. Gr1me s.n. (Mu-1255); Herb. Mus. Bot. Landishuth. s.n. (Mu-320); Herb. Reg. Monac. 8.n. $($ Mu -313$)$; Herb. Schreber 17 (Mu-318); Herb. Schwaegrichen 8.n. (Mun-1256); Hooker s.n. [Onfted States] (Mu-320).

VIERBENA HASTATA 1 . ALBIFLORA Holdenke

Additional bibliographs: Moldenke, Phytologla 282217 (1974) and $30: 176.1975$.

VERBEIM HASTATA P. CAERULEA Moldenke

Additional synorym: Verbens americana, urticae folils angustiorlbus, flore coervileo P. Herm., Hort. Acad. Lugd.-Bat. Cat. 699. 1687. Verbena americana urticae foltis angustioribus, spica multiplici flore caeruleo P. Herm., FI. Lugd.-Bat. 54-55. 1690. Verbena urtica fol. angugtior flore coerul. Herb. ex Rivin., Introd. Gen. Ren Herb. Ord. P1. Irreg. Monop. [24], pl. [57]. 1690. Verbens altissims americans spica multiplici, urticae foli1s angustis, Noribus caervieis P. Hern., Parad. Bat., 
od. 1, 242. 1698. Verbena americana urticae fol11s angustioribus, flore caeruleo Vlor1s., PI. H1st. Untv. Oxon. 3: "408" [=418]. 1699. Verbena altissima americana, sp1ca multiplic1, urticae fol11s angustis, floribos coervle1s Herm. apud Ray, Hist. Plant. 3: Suppl. 286. 1704. Verbens altissima americans opica multiplicl urticae follis angustis, floribus coervleis P. Herm., Parad. Bat., od. 2, 242. 1705. Verbens; americana; altissima; urticae follis angustiorlbes; spicis brevioribus; floribus caeruleis Herm. apud Boerh., Ind. Alt. Plant. Hort. Acad. Lugd., ed. 2, 12 186. 1720. Verbens mer1cane altissima, urticae folile angustioribus, spicie brevlbus. Florlbus ceerule1s Boerh. apud L., Hort. Cl1ff., Imp. I, 11, In syn. 1737. Verbena americans altissina, urt1cae fol11s angustioribus, spicis brevioribus, florls caeruleis Boorh. apud 4 . van Toyen, F1. Leyd. Prod. 327, in syn. 1740. Vorbena americana altissima, spica multiplici, urticse folils angustis, floribus caeruleis Ray apud L., Hort. Ups. 8, In syn. 1748. Verbens amer1cans altissims, spici multiplic1, urticaefoli1s angustis, floribus caervilats Hers. ex I., Sp. P1., od. 1, 1mp. 1, 1: 20, In syn. 1753. Verbens americana altissima, spica mult1plici, urticae foli1s angustis, floribus coerule1s Ray apud J. F. Gronov., FI. V1rg., ed. 2, 4, in syn. 1762. Verbena americana, altissima, spicê multiplici, urticsefoli1s angustis, floribus cearuleis Hermo apud Poir. In Lam., Bncycl. M6th. Bot. 8, 546, in syn. 1808. Verbena americans altiss., spica multipl., urticae fol. angustis, n. coervle1s Herm. apud H. B. R1chter, Cod. Bot. Linn. 35, in syn. 1835. Verbens amer. urticae fol. angustiorib., fl. caeruleo vor 1s apud H. E. Richter, Cod. Bot. Linn. 35, in syn. 1835. Verbena americans, spics multiplici, foli1s urticae angust1ssimis, florlbus eserule1s Herm. ex Yoldenke, Résume Suppl. 4: I4, in syn. 1962.

Additional bibliography: L., Hort. Cliff., imp. 1, 11 (1737) and imp. 2, 11. 1968; Moldenke, Phytologie 28: 217, 426, \& 427 (1974) and 31: 409. 1975.

VBRBENA HASTATA $P$. ROSEA Cheney

Additional bibilography: Koldenke, Phytologia 28: 352, 451, 464, \& 465. 1974 .

VERBENA HASTATA Var. SCABRA Moldenke

Additional bibllography: D. S. \& H. B. Correll, Aquat. \& Wetland P1. ST. U. S., 1mp. 2, 2: 1396, 1399, \& 1775. 1975; A. L. Moldenke, Phytologia 31: 415. 1975; Moldenke, Phytologia 30: 14,6148 (1975), 31: 374 \& 376-378 (1975), and 34: 248-251. 1976.

Recent collectors have encountered this plant in moist soll, molst sandy losm, and molst losw at seeping springs in open grassland, at the edge of ponds, in Populue-Prosopis-Tanarix communities, and in the drier areas of bogs (as the typical form), 
but also in "badly-overgrazed pastureg" (as the fleld form) - in fact, it has been described by some as a "weed in horse pastures", a typical fleld form habitat.

In addition to the months previously reported, it has been found in flower in October and at 4600 feet altitude (in Utah). Crutchfield reports it attaining a height of 6 feet (like the typical form and unlike the usual "fleld form". Material has sometimes been misidentified and distributed in herbaria as V. stricte Vent. and as "V. hasta L."

The corolles are said to have been "purple" on Crutchfield 3525 and "deep-purple" on Crutchfleld 3551 when Presh, 88 in the typ1cal form.

The Spellenberg \& Spellenberg 2082, distributed as V. hastata var. scabra, actualiy is V. macdougalif Heller.

Additional citations: INDIANA: Tippecanoe Co.s Bresinsky s.n. [Lafayette, 12.7.1967] ( $\mathrm{Yu}$ ). KANSAS: Duckinson Co.: A. R. Moldenke 1297 (Ld). UTAH: Utah Co.: Woodcox 55 (Au-122283). MEBRASKA: Plerce Co.: N. F. Petergen s.n. [Aug. 10, 1910] (Lv, Iv). OKJLAHOUA: Ottawa Co.: Correll \& Correll 3984h (Ld). TEXAS: Hemphill Co.: Crutchfield 3525 (Ld); E. Lo Reed 4034 (Au-122282); Tharp 4504 (Au-122281). Hutchinson Co.: Crutchfield 3551 (Id). Oldham Co.: York \& Rodgers 363 (Au-201798). Potter Co.: Higgins 9712 (N). ARIZONA: Coconino Co.: MacDougal 566 (Au-122291). WASHINGTON: Yakima Co.: Moldenke \& Moldenke 2123 (Ld). OREGON: Maltnomah Co.: G1lkey s.n. [July 31, 1945] (Au-122290).

VERBENA HATSCHBACHI Moldenke

Add1tional bibliography: Moldenke, Phytologie 28: 352. 1974. The corolles are sald to have been "violet" in color when fresh on Hatschbach 8558 .

Additional citations: BRAZIL: Parand: Hatschbach 8558 [Herb. Brad. 15182] (Mu).

\section{VERBEN HATEKII Moldenke}

Additional bibliography: Moldenke, Photologia 28: 218 \& 252. 1974; Soukup, Biote 11: 18. 1976.

Richardson refers to this as a scattered prostrate plant in the rocky soll of roadsides, and the corollas on RIchardson 2066 are said to have been "blue".

Additional c1tations: PERU: Junin: Richardson 2066 (Ld).

VERBENA HERRTERI Moldenke

Additional bibliography: Moldenke, Phytologla 28: 352. 1974.

Additional citations: URUGUAY: Herter 979 [Herb. Herter 82378] (Mu-isotype).

VERBENA HIRTA Spreng.

Additional bibliography: Buek, Gen. Spec. Syn. Candoll. 3: 495. 1858; Moldenke, Phytologia 28: 352 (1974), $33: 480$ (1976) and 34 : 259. 1976. 
Recent colleotor have encountered this plant in secondary forests on laterite soll, on campos, in open scrub, in ruderal grasslands, and among ruderal vegetation on hills, flowering and fruiting in May, October, and November. Araujo refers to it as a hellophllous herb "crescendo em pasto a beira do preciploto". The Tryons describe it as "woody at base, $0.5 \mathrm{~m}$. tall". The corollas are sald to have been "11lac" on Dziewn 3, Ferrelra 97, and Kummrow 646 \& 1049, "blue-purple" on Tryon \& Tryon 6713, "blue-purple (5P5/8)" on Lindeman \& Haas 5137, "purpie" on Lindeman \& Haas 300 "murale (2 1/ 12 P6/6" on Lindeman \& Haas 4008, "purple $\left(\frac{1}{1 / 2} \mathrm{P} 6 / 8\right.$ )" on Lindeman \& Hass 18 , "purple $(2 \sqrt{2}$ P $7 / 6 "$ on Lindeman \& Haas 2l4h "purple, tube slightly paler (2 1/2 P5/8-6/4)n on Lindeman \& Haas 2460 , and "red" on Araujo 1262.

On Lindeman \& Hass $24 \overline{60}$ the entire plant is pronouncedly cinnamon-colored, but this $\overline{1 s}$ probably an effect prochuced by a layer of dust from its roadside habitat.

The Dusén s.n. [11.12.903] and Sinith \& Klein 13885, distributed

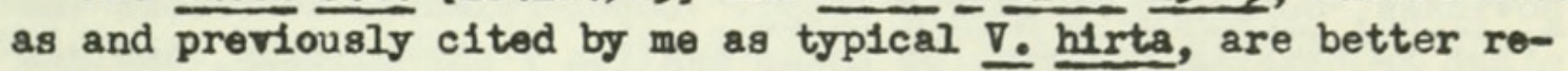
garded as representing var. dusenti Moldenke, of which the former is the type collection.

Additional cltations: BRAzII: Parana: Dz1ewa 3 (Ld); L. F. Ferreira 97 (Ld); Kummrow 646 (Ac), 1049 (Ld), 1123 (Ld); Lindeman \&

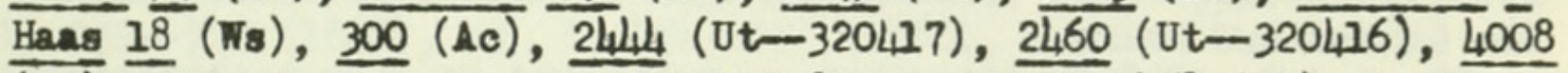
(Id). Rio de Janeiro: Angeli 107 [Herb. FEGaM 345] (Ld); A. Cae-

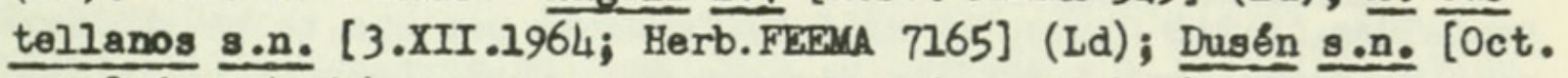
1903] (Mu-4251); I1ndeman \& Hass 5137 (Ut-320428); Tryon \& Tryon 6713 (N). R10 Grande do Sul: Aranjo 1262 [Herb. FEIBMA 12280] (Pf). Sants Catarins: A. Castellanos 24675 [Herb. Cent. Pesq. Florest. 3417] (Fe). Stato undetermined: J. E. Pohl s.n. $(\mathrm{Mu}-57 \mathrm{n})$.

VERBENA HIRTA var. DUSENII Moldenke, Phytologia 33: 480. 1976.

B1bliography: Moldenke, Phytologia 33: 480 (1976) and 34: 259. 1976.

Collectors have found this plant growing on campos, on campos near the borders of planaltos, and in low woods, at $900-1000 \mathrm{~m}$. altitude, flowering in November and December. Hitherto it has been eonfused with, and materlal has been distributed as, typical V. hirta Spreng.

C1tations: BRAZIL: Paraná Dusén s.n. [1].12.903] (N-type); Lindeman \& Hass 3251d (Ut-320广15). Santa Catarina: Smith \& Klein

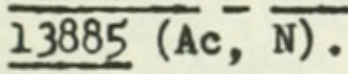

VERBENA HIRTA var. GRACIIIS Dusén

Additional bibllography: Moldenke, Phytologia 28: 352.1974.

In addition to the months previously reported, this plant has been found in fruit in October. The corollas are said to have been "dark-111ac" on Hatschbach 35191.

The Reitz \& Klein 17616 previously c1ted by me and distributed 
as this variety actually is V. strigosa Cham.

Additional citations: BRUZII: Parand: Hatschbech 35191 (Id).

VERBENA HISPIDA RuIz \& Pav.

Additional \& emended bibliography 2 . Don in Loud., Hort. Brit., ed. 1, 247 (1830) and ed. 2, 247. 1832; G. Don in Loud., Hort. Brit. Suppl. 1: 680. 1832; Loud., Hort. Brit., ed. 2, 552. 1832; Baxt. In Loud., Hort. Brit. Suppl. 2: 680. 1839 ; G. Don in Loud., Hort. Brit., ed. 3, 247. 1839 ; Baxt. in Loud., Hort. Brlt. Suppl. [3] : 655. 1850; Buek, Gen. Spec. Syn. Candoll: 3: 494 \& 495. 1858; Bolkh., Grif, Matvej., \& Zakhar., Chrom. Numb. Flow. P1., imp. 1, 717 (1969) and imp. 2, 717. 1974; R. D. Gibbs, Chemotax. Flow. PI. 3: $1753-1755$ (1974) and $4: 2295$. 1974; Kooiman, Act. Bot. Neerl. 24: 464. 1975; Moldenke, Photolog1a 30: 148. 1975; Soukup, Biota 11: 18. 1976; Moldenke, Phytolog1a 36: 33 \& 151. 1977.

Don (1830) calls this the "hispid vervaln" and says that it was Introduced into English gardens from Peru in 1816. The corollas are described as having been "violet" in color when fresh on Krapovickas, Schinind, \& Quarin 26557. I6pez-Palacios describes the plant as "hierba rastrera de hbjas sésiles y mus piloses, espigas cillindricas y relativamente engrosadas".

Gibbs (1974) reports that cyanogenesis and levcoanthocyantn are absent from the leaves of this species and syring in is absent from the stems, while the Juglone test gives negative results in the leaves and bark.

The Pedersen 9867, c1ted below, collected in clay soll along roadsides In the Chaco, is sald by Troncoso perhaps to be $x V$. dermeni Moldenke, but I fail to discern the hybrid characters in the specimen cited. The Pavon collection cited below may be part of the type collection. The Herb. Kummer s.n. [Hort. bot. Monac.] is a mixture with $\mathrm{V} . \mathrm{M}$ gida Spreng.

The Buchtien s.n. [Valdivia, 7/11/1902], distributed as V. hispida, actually is $\bar{V}_{0}$ bonariensis L., while W. Forster s.n. [8.I. 1954] is V. parvula Hayek.

Additional citations: ECUADOR: Loja: L6pez-Palac10s 4163 (Id). PERU: Province undetermined: Pavon s.n. $(\mathbf{M n}-1257)$. BOLIVIA: La Paz: 0. Buchtien 8426 (Mu). CHILE: Valpariso: Zöllner 8100 (Gz). ARGENTINA: Chaco: Pedersen 9867 (N). Jufuy: Cabrera, Ancibor, Re, Tello, \& Torres 15080 (Mu); Krapovickas, Schinini, \& Quarin 26557 (Id). Mendozs: Semper s.n. $\overline{[12-18 / I I I / 944](U t-330561 B) .} \frac{1}{\text { CULTI- }}$ VATED: Germany: Herb. Kummer s.n. [Hort. bot. Monac.] (Mu-1276); Herb. Zucearini s.n. [Hort. bot. Monac. 1836] (Mu-326), s.n. [Hort. bot. Monac. 1837] (Mu-284), s.n. [Hort. bot. Monac.] (Mu325).

VERBENA HOOKERIANA (Covas \& Schnack) Moldenke

Additional \& emended bibliography: Buek, Gen. Spec. Syn. Candoll. 3: 494. 1858; Bolkh., Grif, Matvej., \& Zakhar., Chrom. Numb. Flow. P1., Imp. 1, 715 \& 717 (1969) and imp. 2, 715' \& 717. 1974; 
Moldenke, Phytolog1a 30: 148 (1975) and 36: 149. 1977.

The corollas on Lossen 8 are said to have been "violet" in color when fresh.

Additional c1tations: ARGENTINA: C6rdoba: Lossen 8 (Mu-4370). R1o Negro: O'Donell 1553 (Ut-330530B, Ut-33071B).

VERBENA HUMIFUSA Cham.

Additional b1bllography: Buek, Gen. Spec. Syn. Candoll. 3: 495. 1858; Moldenke, Phytologia 28: 353. 1974.

Relneck \& Czermak 21 is a mixture with V. marrubioides Cham.

Additional \& emended citations: BRAZII: Rio Grande do Sul: Re1neck \& Czermak 2l, in part [Herb. Osten 4160] (Mu, N, N-photo,

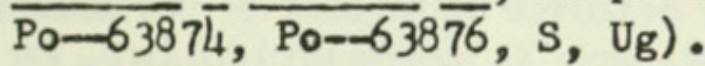

xVBRBENA HYBRIDA Voss in Vilm., Fl. Pleine Terr., ed. 1, 936. 1865 [not V. hybrida B1cknell, 194l].

Additional \& emended synoryuly: Verbena hybrida Vossler apud L6pez-Palacios, Revist. Fac. Farm. Univ. Los Andes 15: 89. 1975; Moldenke, Phytologia 30: 149, in syn. 1975. Glandularia hybrida (Vossl.) Lopez-Palacios, Revist. Fac. Farm. Univ. Los Andes 15: 89. 1975. Verbena gend1 Hort. ex Moldenke, Phytologia 34: 279, in syn. 1976.

Additional \& emended bibliography: Vilm., Fl. Pleine Terr., ed. 1, 939-942 (1865), ed. 2, 976-979 (1866), and ed. 3, 1: 12001203. 1870; Vilm., FI. Pleine Terr. Suppl. 195. 1884; Cooke, F1. Pres1d. Bombay, ed. 1, 3: 437. 1906; Knoche, FI. Balear., Imp. 1, 1: 59. 1921; Wangerin in Just, Bot. Jahresber. 46 (1): 717. 1926; A. W. Anderson, How We Got Fls., imp. 1, 90 \& 283. 1951; Conard, P1. Iowa 44. 1951; Cooke, F1. Presid. Bombay, ed. 2, imp. 1, 517518. 1958; A. W. Anderson, How We Got Fls., imp. 2, 90 \& 283. 1966; Cooke, FI. Presid. Bombay, ed. 2, imp. 2, 2: 517-518. 1967; Bolkh., Grif, Matrej., \& Zakhar., Chrom. Numb. Flow. PI., Imp. 1, 717. 1969; G. W. Thomas, Tex. PI. Ecolog. Summ. 78. 1969; R. E. Harrison, Handb. Bulbs \& Peren. S. Hemisph., ed. 3, 266-267. 1971; Healy, Gard. Guide PI. Names 225. 1972, Willianson, Sunset West. Gard. Book, imp. 11, 437. 1973; Bolkh., Grif, Matvej., \& Zakhar., Chrom. Numb. Flow. PI., imp. 2, 717. 1974; Knoche, FI. Balear., 1mp. 2, 1: 59. 1974; Hocking, Excerpt. Bot. A.26: 5 . 1975; Kooiman, Act. Bot. Neerl. 24: 464. 1975; L6pez-Palacios, Revist. Fac. Farm. Univ. Los Andes 15: 89. 1975; Moldenke, Phýtologia 30: 148-151 \& 163 (1975), 31: 398 \& 410-412 (1975), and 34: 263, 270, \& 279. 1976; Park Seed Co., Park Seeds Fls . \& Veg. 1976: 63 \& 90. 1976; Soukup, Biota 11: 18. 1976; Moldenke, Phytologia $36: 40$ \& 140.1977.

Additional illustrations: Voss in Vilm., Fl. Plelne Terr., ed 3, I: 1200 \& 1201. 1870; R. E. Harrison, Handb. Bulbs \& Peren. S. Hemisph., ed. 3, 267. 1971; Park Seed Co., Park Seeds Fls. \& Veg . 1976: 90 (in color). 1976.

Misra (1970) makes the remarkable statement that $x V_{0}$ hybrlda is a "Weed In shade" in B1har, Ind1a, but Mukherjee 2lso says of 
it: "annual herb of waste places" in West Bengal. It would be interesting to know what cultivars are involved here and if they are breeding true or reverting to one of the several ancestral species. Blakeslee (1926) discusses the observed unlike reactions of different human individuals to the fragrance in Verbena flowers.

I6pez-Palacios (1975), who found the red-flowered cultivar in cultivation at $1600 \mathrm{~m}$. altitude in Ecuador and who credits the name to Vossler Instead of to Voss, couments that "Esta hermosa planta jardánica esté extendida por todo el territorio nacional [Venesue1a]. Schauer, al hablar de la V. peruviana, de la que proceden las razas de flores rojas de la V. hybrida, dice: 'Planta floribus magnis splendide scarlatines maxime spectabilis, hortorum europeorum nunc tamen eximium decus.....eleganti colorvm et follorum varletate excelentes," Apud DC. Prodromas 9: 537, sub V. chamaedrifolia. Lo que puede decirse no sblo de los jardines europeos, sino de todas las partes del mundo." Actually, of course, V. peruviana is NOT widely cultivated in gardens any more and has been replaced by the very common $x V$. hybrida, among whose multitudinous color forms I have never yet seen anything to match the brilliant splendor of the true wild V. peruviana!

Stewart (1972) cites the accepted binomial for this species as "V. hybrlds Hort. ex Vilm. FI. PI. Terre Suppl. 195. 1865", but the only Supplement to this work exdeting either in the New York or Washington libraries is a supplement to edition 3 of 1884 .

Knoche (1921) reports that in the Balearic Islands this plant Is called "carmelita" and is there cultivated. Duque-Jaramillo found it in flower and fruit in March at 2620 meters altitude in Colombian gardens. Thomas (1969) calls it the "hybrid verbena". Williamson (1973) lists the very modern horticultural varieties "Amethyst" and "Miss Susie".

The Ardoin 2I, distributed as XV. hybrida, actually is V. rigIda Spreng.

Additional citations: COLOMBIA: Cauca: Ibpez-Palacios \& Idrobo 3832 (Ac). INDIA: West Bengal: Mukherjee s.n. [12.9.74] (Id). CULTIVATED: Colombia: Duquo-Jaramillo 2990 (N); Ibpez-Palacios 3616 (Id, N) . Czechoslovada: Presl s.n. (Mu-4372) . Bcuador: L6pez-Palacios 4177 (Id). Germany: 011n s.n. [June 1893] (Ac).

XVERBENA IIUICITA Moldenke

Additional bibllography: Perkins, Estes, \& Thorp, Bull. Torrey Bot. Club 102: 194, 195, \& 197. 1975; Moldenke, Phytologia $30:$ 151 (1975), 34: 250 (1976), and 36: 157. 1977.

Perkins and his associates (1975) report finding this hybrid to be the most abundant of four natural bybrids occurring in a single area in Oklahoms, there having been about 20 individuals of it as compared to 10 of $x \nabla$. goodmant Moldenke, 1 of $x \nabla$. deamil Moldenke, and 1 of $x \mathrm{~V}$. perrian Moldenke. A single artificially cross-pollinated plant (using $\nabla_{0}$ urticifolia L. pollen) with 168 potential seeds had a 12.5 percent seed-set, while the parental 
species, V. urticifolla, had $47.3-66.5$ percent seed-set and V. stricta Vint. (when insect-poll1nated) had $76.3-87.6$ percent.

Additional c1tations: IIIINOIS: Cass Co.: Geyer s.n. [Beardstown, July 1842] (Mu-4l1). MSSOURI: Salnt Lou1s: Engelmann 8 . n. [St. Louls] ( $\mathrm{Mu}--4 \mathrm{L2})$.

VERBENA INAMOENA Briq.

Additional b1bllography: Moldenke, Phytologia 30: 151 (1975), $34: 279$ (1976), and 36: 131. 1977.

T. Rojas 10077, cited herein under V. bonariensis L., has been annotated by an unknown hand as "Verbena bonarlensis L. $f$. trans1ens In V. Inamoman Briq." The Herb. Mus. Bot. Landishuth s.n., also cited by me as $\mathrm{V}$. bonarlensis, has all its leaves very narrowoblong In shape and may represent $V_{0}$ inamoena instead.

VIRRBENA INCISA Hook.

Additional synonyul: Verbena arenaria Higel ex Moldenke, Phytologia 34: 278, in syn. 1976 [not V. arenar1a Moldenke, 1961]. Verbena arenariana Kumer ex Moldenke, Phytologia $34: 278$, in syn. 1976.

Additional bibllography: G. Don in Iond., Hort. Brit. Suppl. 1: 680. 1832; Loud., Hort. Brit., ed. 2, 552. 1832; Baxt. In Loud., Bort. Brit. Suppl. 2: 680. 1839; G. Don in Loud., Hort. Brit. Suppl. 2: 704. 1839; Baxt. In Loud., Hort. Brit. Suppl. [3] : 655. 1850; Vilm., F1. Plelne Terre, ed. 1, 939 (1865), ed. 2, 2: 976 \& $977(1866)$, ed. 3, 1: $1200(1870)$, and ed. 4, 1067. 1894; Moldenke, Phytologia 30: 150-152, 163, \& 172 (1975), $31: 392$ \& 412 (1975), and 34: $270 \& 278.1976$.

The corollas on Cristóbal 1210, Fabris 4688, and Krapovickas \& 2l. 25759 \& 27068 are described as having been "red", whille on Herzog 1217 they were "cinnabar-red" and on Pflanz 251 "scarletred".

The cheiromymous $V_{\text {. }}$ arenaria and $V_{\text {. }}$ arenariana listed in the synonymy above are based on specimens in the Nunich herbarium collected, respectively, by Fugel in the Vienna and by Kummer in the Munich botanical garden. Don (1839) calls this species "Lady Arran's verbena".

Material of this species has been misidentified and distributed in some herbarla as $\nabla$. phlogiflor Cham.

Additional c1tations: BRAZII: Rio de Janeiro: Cabral s.n. [28. I. 1963 ; Herb. FEJMA 5192] (Fo). Rio Grande do Sul: Borraiiller I43 (Mu--4290). BOLIVIA: Santa Cruz: Herzog 1217 (ku). Tar1ja: Pflanz 951 (Mu). PARAGUAY: T. Rojas 3406 [Hort. Parag. 17793] (Yu) . URUGUAY: Herb. Herter 84884 (Mu); Herter 1057 [Herb. Hertor 82947] (Mu). ARGBNINA: Catamarca: Rodriguez Vaquero 349 (Ut330568B). Corrientes: Cr1st6bal 1210 (Id); Krapovickas, Cristobal, Irigoyen, \& Schinint 27068 (Id); Krapovickas, Cristobal, Schinin1, Arbo, Quarin, \& Gonz 
(Mu). Misiones: Bertoni s.n. [Herb. Inst. M. Lillo 98412] (Ld); Montes 14662 (N). CULTIVATFD: Austria: Hïgel s.n. [hort. Hiigel V1ndob. 1839] (Mu-303). Germans: Herb. Kummer s..n. [Hort. bot. Monac. 1840.IX.13] (Mu-1260, Mu-126I), s.n. [Hort. bot. Monac.] (Mu-1259). Swoden: Zetterstedt s.n. [H. L. 10 Oct. 1839] (AC).

VERBENA INTEGRIFOLIA Sessé \& Moc.

Additional \& emended bibliography: Bolkh., Orif, Matrej., \& Zakhar., Chrom. Numb. Flow. P1., Imp. 1, 717 (1969) and 1mp. 2, 717. 1974; Moldenke, Phytologia 28: 246. 1974 .

xVERBENA INTERCEDENS Briq.

Additional bibliography: Moldenke, Phytologia 28: 246 \& 440 . 1974 .

VERBENA INTERMEDIA Gill. \& Hook.

Additional \& emended blbllography: Buek, Gen. Spec. Syn. Candoll. 3: 494--496. 1858, Bolkh., Grif, Matvej., \& Zakhar., Chrom. Numb. Flow. P1., imp. 1, 717 (1969) and 1mp. 2, 717. 1974; Moldenke, Phytologia 30: 152 (1975) and 31: 387 \& 409.1975.

Pedersen encountered this plant on "black earth" grasslands in Corrientes and Job found it on dunes in Buenos Alres. The corollas on Herter 1155 are said to have been "lilac-blue" when fresh.

Additional citations: URUGUAY: Herter 1155 [Herb. Herter 83295] (Mu). ARGENTINA: Buenos A1res: Job 1597 (Ut-330533B). Corrientes: Pedersen 4660 (N).

VERBENA JORDANENSIS MOIdenke

Additional bibliography: Moldenke, Phytologia 28: 354 (1974) and 30: 192. 1975 .

VERBENA KUHLMANNII Moldenke, Phytologia 31: 29. 1975.

Bibliography: Moldenke, Phytologia 31: 29 \& 387. 1975; Anon., B101. Abstr. 61: AC1.732.1976.

Citations: BRAZIL: S\&o Paulo: M. Kuhlmann 377 [Herb. Inst. Bot. S. Paulo 79535] (w-2748267-type, 2-photo of type, Zphoto of type).

VIRBENA LACINIATA (I.) Briq.

Additional bibliography: Sweet, Hort. Brit., ed. 2, 419. 1830; G. Don in Loud., Hort. Brit., ed. 1, 247 (1830) and ed. 2, 247. 1832; G. Don in Loud., Hort. Brit. Suppl. 1: 680. 1832; Loud., Hort. Brit., od. 2, 552. 1832; Baxt. in Loud., Hort. Brit. Suppl. 2: $680.1839 ; G$. Don in Loud., Hort. Brit., ed. 3, 247. 1839; Baxt. In Loud., Hort. Brit. Suppl. [3]: 655. 1850; Buek, Gen. Spec. Syn. Candoll. 3: 494 \& 495. 1858; V1Im., F1. Pleine Terr., ed. 1, 937 (1865), ed. 2, 2: 974 (1866), ed. 3, 1: $1197-1198$ (1870), and ed. 4, 1066 \& 1070. 1894; A. W. Anderson, How Wo Got Fls., imp. 1, 168 \& 283 (1951) and imp. 2, 168 \& 283. 1966;

Bolkh., Grif, Matrej., \& Zakhar., Chrom. Numb. Flow. P1., imp. 1, 
715-717 (1969) and 1mp. 2, 75-717. 1974; Hinton \& Rzedowsk1, Anal. Esc. Nac. Clenc. Biol. 21: 111. 1975; Kooinan, Act. Bot. Neer1. 24: 464. 1975; López-Palac1os, Revist. Fac. Farm. Unív. Los Ander 15: 94. 1975; Moldenke, Phytologia 30: 152-153 \& 172 (1975), 31: 383, 410, \& 421 (1975), and 34: 259 \& 260. 1976; Soukup, Biote 11: 19. 1976; E. H. Walker, F1. Ok1n. \& South. Rguk. 884. 1976; Moldenke, Phytologia 36: 128, 139, \& 148. 1977.

Additional illustrations: Voss in Vilm., Fl. Pleine Terr., ed. 4, 1066. 1894 .

Fosberg encountered this plant in grassy places grazed by goats on the top of a low hill and the corollas on no. 27645 are said to have been "lavender" when fresh, while on Grandjot s.n. [XI.32] they were "rose-violet" in color.

Don (1830) lists V. multifida Rulz \& Pav, as a synonym of V.

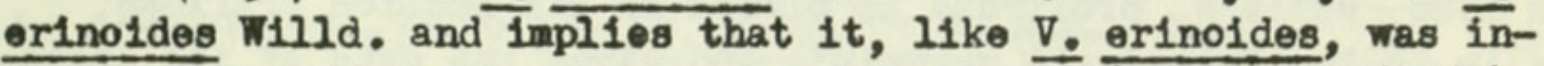
troduced into English gardens from Peru in 1818. Tawada (1967) reports "V. erino1des Lamarck" as cultivated in Okinawr, but probably this is an error in identification for $V$. temulsecta Briq. It should be noted here that Walker (1976) gives "1968" as the correct publication date for Tawada's work.

The Lorentz 478, distributed as V. laciniata, actually is V. aristigera S. Moore, while Merxauller 24804 is V. berteri1 (Me1sn.) Schan., Collector undetermined s.n. [H. L. 1840], is V. bipinnatifida Nutt., Lossen 72 is V. glandulifera Moldenke, Herter 1805 and Herb. Herter 96556 are V. pulchella Sweet, Martius s.n. [ad S. Joab d'kl Rey, Febr.] is V. regnelliana Moldenke, Herter 181 and Herb. Herter 79174 are V. sello1 Spreng., and Brlale s.n., Herb. Hort. Monac. s.n., and Herb. Merrominler 14336 , as well as Kupper s.n. [cult. h. b. M.] are $v_{0}$ teruisecta Briq.

Additional citations: ECUADOR: Caffar: Herb. Univ. Cent. Quit to 2350 (ku). Chimborazo: F. R. Fosberg 27645 (N) . BOLIVIA: La Paz: 0. E. White s.n. [2-18-1963] (W-2774548). CHILE: Concepcion: Neger s.n. [1893-96] (Yu-3981). Malleco: Baeza s.n. [19.XII.

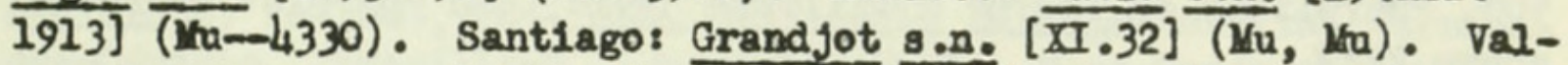
para1so: Bohn s.n. [Quillpué, 2.X.1932] (Mu), s.n. [Valpara1so, I Okt. 1922] (Yu); 0. Buchtion s.n. [8.IX.1895] (Yu-1837); Kausel s.n. [Limache, 16.X.27] (1.n). Province undeterminod: Dusén s.n. [Chill australis 1896-97] ( $\mathrm{ku}-2982)$; Reuca s.n. [1889] ( $\mathrm{ku}=$ 4322). YOUNTED ILLUSTRATIONS: Rufz \& Pav., F1. Peruv. \& Chill. I: pl. 33, f1g. 2. $1797(\mathrm{~N}, \mathrm{Z})$.

VERBENA LACINIATA var. COMTRACTA (Lindl.) Moldenke

Additional bibliographys $G$. Don in Loud., Hort. Brit., ed. 1, 247 (1830), d. 2, 247 (1832), and ed. 3, 247. 1839; Bext. in Loud., Hort. Brit. Suppl. [3]; 655. 1850; Buek, Gen. Spec. Syn. Candoll. 3: 494 \& 495. 1858; Moldenke, Phytolog1a 30: 153 (1975) and $31: 410 \& 411.1975$.

Don (1830) calls $\nabla_{0}$ erinotdes the "Erimus-11ke vervaln" and 
claims that it was introduced into English gardens from Pern in 1818 probably in this contracted form.

VERBENA IASIOSTACHYS IInk

Additional bibliography: Sweet, Hort. Brit., ed. 2, 418 \& 419. 1830; G. Don in Loud., Hort. Br1t., ed. 1, $246^{\prime} \& 247$ (1830) and ed. 2, 246 \& 247. 1832; Loud., Hort. Brit., ed. 2, 552. 1832; G. Don in Loud., Hort. Brit., ed. 3, 246 \& 247. 1839 ; Buek, Cen. Spec. Syn. Candol1. 3: 495. 1858; Kooiman, Act. Bot. Neerl. 24: 464. 1975; Moldenke, Phytologia 30: 153 (1975), 34: 251 (1976), and $36:$ 135. 1977.

Don (1830) places V. lasiostachys in his Section Indivisae (with undivided leaves), calls it the "hairy-spiked vervain", and says that it was introduced into English gardens from Californta in 1826, while V. prostrata is placed in his Section Trifldae, calls it the "prostrate vervain", and gives the date of its introduction from "N. Amer." as 1794.

The Herb. Schwaegrichen s.n. [1837], Herb. Zuccarini s.n. [Hort. Bot. Monac. 1835, 1836], Raven 2951, and Thorme \& Tilforth 39918 , distributed as typical V. Iasiostachys, actually seem to represent var. septentrional1s Moldenke, wh1le Meebold 20234 is V. robuste Greene.

Additional c1tations: CAIIFORNIA: Humboldt Co.: Moldenke \& Moldenke 30232 (Ac, Gz, Kh, Id, In, Mu, Tu, Ut, W). Santa Barbara Co.: Meebold 2211 (Mu). Sants Crus Co.: M. E. Jones 2215 (Mu1575).

VERBENA LASIOSTACHIS var. SEPTENTRIONAIS MOIdenkE

Additional bibliography: Moldenke, Phytologia 30: 153 (1975) and $36: 135.1977$.

Recent collectors have encountered this plant in dry places and "a few feet above high-tide line on cosstal cliffs", at altitudes of 2-30 metere, and describe it as a widely branching herb, $6 \mathrm{~cm}$. tall. The corollas are said to have been "blue" on Witham 508, "purplish" on Thorne \& Tilforth 39918, and "purple" on Beavchamp 2523.

Material of this variety has been misidentified and distributed In some herbaria as $V_{0}$ bracteata Lag. \& Rodr.

Additional citations: ORECON: Josephine Co.: Baker \& Ruhle 434 (N). CALIFORNIA: Alameda Co.: Meebold 19930 ( Ha 3 NIchener \& Biolett1 s.n. [Oakland, June 1891] (MI). Butte Co.: Moldenke \& MoIdenke 30339 (Gz, Mu, Tu, Ut). Los Angeles Co.: Gallup s.n. $[\overline{8 / 13} /$ 1949] (Sd-72252); Meebold 20050 (Mu); Thorne \& Tilforth 39918 $(\mathrm{KI}-16018)$. Nevada Co.: M. E. Jones 2598 (In-70251, Mu-1576). San Diego Co.: Beauchang 2523 (Sd-85664); Y. F. Spencer 1037 (Mu4319); Withan 1454 (Sd-80427). San Iuis Obispo Co.s Edr. Palmer $342(\mathrm{Mu}-1555)$; Raven 2951 (Ac); Witham 508 (Sd-7574). Shasta

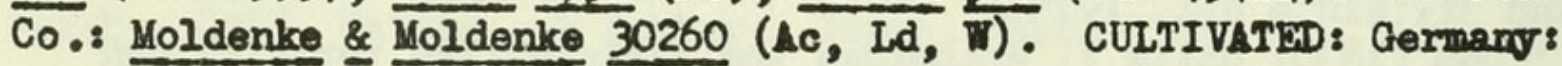


Herb. Schwaegrichen s.n. [1837] (Mu-1267); Herb. Zuccar1nt s.n. [Hort. Bot. Monac. 1835] $(\mathrm{Mu}-367)$, s.n. [Hort. Bot. Monac. 1836] $($ Mu-368). s.n. [Hort. Bot. Monac.] (Mu-369).

VERBENA LILACINA Greene

Additional bibliography: Moldenke, Phytologia 30: 153. 1975.

Recent collectors describe this spectes as a dense bush or subshrub, 2-5 feet tall, growing in the steep north slopes of canyons, along the sides of large grantte boulders, at altitudes of 5-50 meters, flowering and fruiting in March, April, and July. Moran reports it as "common in arroyos". The corollas are sa1d to have been "lavender" in color on Moran 17123, 1727, \& 17185 .

Add1tional c1tations: MEXICO: Baja California: Bostic s.n. [2 July 1969] (Sd-70839); R. V. Moran 17123 (Sd-76988), 프른 76989), 17185 (Sd-76987).

VERBENA LINDBERGI Moldenke

Additional bibliography: Moldenke, Phytologia 23: 288 (1972) and 31: 387.1975.

Merxaiuller encountered this species at 2350 meters altitude, flowering in December.

Additional citations: BRAZIL: R10 de Jane1ro: Merxmitiler $25555(\mathrm{Mu})$.

VERBENA LIPOZYGIOIDES WaIP.

Additional blbliography: Buek, Gen. Spec. Syn. Candoll. 3: 495. 1858; Moldenke, Phytolog1a 28: 354. 1974 .

VERBEMA LITORALIS H.B.K.

Additional synonym: Verbena atriote Pabst ex Noldenke, Phytologia $34: 278$, in syn. 1976 .

Additional \& emended bibllography: $G$. Don in Loud., Hort. Brit. Suppl. 1: 680. 1832; Baxt. In Loud., Hort. Brit. Suppl. 2: 680 (1839) and [3] : 655. 1850; Buek, Gen. Spec. Syn. Candoll. 3: 494 \& 495. 1858; Robledo, Bot. Med. 392. 1924; Barriga-Bontlla, Hernández-Camacho, Jaramillio-T., Jaramillo-Mejla, Mora-Osejo, PintoEscobar, \& Ruiz-Carranza, Isla San Andrés 59. 1969; O. W. Thomas, Tex. Pl. Ecolog. Summ. 78. 1969; Bolkh., Grif, Matvej., \& Zakhar., Chromb. Numb. Flow. P1., imp. 1, 717. 1969; Hartwell, Lloydia 34: 387. 1971; Bolkh., Grif, Matvej., \& Zakhar., Chrom. Nhmb. Flow. P1., Imp. 2, 717. 1974; Gibbs, Chemotax. F10w. P1. 3: 1753 \& 1754 . 1974; Balgooy, Pac1f. P1. Areas 3: 245. 1975; 0. \& I. Degener \& Pekelo, Hawa11. P1. Names x.4, x.21, \& x.22. 1975; Hinton \& Rzedowsk1, Ann. Bsc. Nac. Cienc. Biol. 21: 31 \& 111. 1975; Kooiman, Act. Bot. Neerl. 24: 464. 1975; Lopez-Palacios, Revist. Fac. Farm. Univ. Los Andes 15: 51 \& 90-93, fig. [17]. 1975; Molina R., Ceiba 19: 95. 1975; Tovar Serpa, B1ota 10: 286 \& 298. 1975; Moldenke, Phytologia 30: 136 \& 153-154 (1975), 31: 378, 379, 383, \& 392 (1975), and 34: 256, 260, 267, 270, \& 278. 1976; Ĺbez-Palacios, Revist. Fac. Fam. Univ. Los Andes 17: 50. 1976; Soukup, Blots il: 
19. 1976; E. H. Walker, F1. Okin. \& South. Ryuk. 883 \& 884. 1976; Moldenke, Phytologia 36: 31, 33, 47, 51, 52, 122, 131, 136, 137, \& 151. 1977 .

Additional 1llustrations: López-Palacios, Revlst. Fac. Farm. Univ. Los Andes 15: fig. [17] . 1975.

Molina $R$. refers to this species as a "weed common in sugarcane plantations" in Nicaragua. Walker (1976) calls it "A weed of roadsides and waste places" on Okinawa, while Schlieben reports it "very abundant" on bush savannas in the Transvaal. On Saipan island Stone found it to be a "common weed with Asclepias curassavica, Conyza, Cardiosperrmum, etc." Herbst speaks of it as "uncomnon" on Hauai 1sland. Werff found it in the molst zone on Chatham 1sland in the Galapagos and comments that there its flowers were "not as intensely colored as those of 2182 [V. brasiliensis Vell.]". Blanco describes it as $0.8--1.3$ meters tall and "medicinal" in Venezuela; Taylor found it on steep roadside banks in Costa Rica.

The inflorescence tips on Molina $\mathrm{R} .2724 \mathrm{~L}$ are much congested because they are insect-galled; the corollas are said to have been "lilac" in color when Presh, as they were also on his no. 11508 , on Hatschbach \& Kummiow 35764, Romero-Castafioda 10668, and Schlieben 7691 . They are said to have been "violet" on Pabst 7372 and Schinini \& al. 10259, "blue" on Behn 8.n. [14 Decbr. 1930], "blueviolet" on P1owman \& Dav1s 4889, "bluish-violet" on Stone 5233, "pretty purple" on Clemens 42170, and "pale-blue" on Herbst 2296. On Lbpez-Palacios 4220 \& 4332 they are described as "moradas", on 4196 "morado 111a", on 4100 "111a", and on 4040 "azul morado hasta morado muy claron".

Hatschbach \& Kummrow report V. litoralis being used medicinally in Braz1l, while in Peru, according to Plowman \& Davis, the dried ground-up leaves are placed on wounds.

It is not certain to what species Gibbs (1974) is referring when he uses the name "Verbena arborea", but such a binomial has been used for $V$. litoralis in the horticultural trade.

Lobez-Palacīos (1975) comments that "En Paris, en el Herbario HB, existe el N. 658 [of Bompland], determinado como V. caracasana, que bien puede ser el tipo o, cuando menos, el esbtipo" [or var. caracasana]. He contimes: "Yo he examinado el material de Willdenow y no encuentro diferencia alguna con la V. litoralls HBK. El especimen 11134 Willd., Verbena lanceolata, corresponde al 638 de Humboldt (P), rotulado quizás por 61 mismo, o por Bonpland, V. caracasana, pero on mi concepto, no creo que alconce ni siquiera a una diferencia de variedad de la V. litoralis. También las poblaciones son aguales, $\mathrm{y}$ no se observa diferencia entre las de Caracas y las de Mérida, p. e. De la V. glabrata no hay constancia segura de que exdsta en el territorio venezolano. EI ejemplar de Mocquerys, Duaes 893 ? No o fecha?), determinado por Dofia N. Troncoso como V. glabrate es, simplemente, V. litoralis. 
Wuchos las consideran como coespecfficas.....Para mi es diffcil establecer la diferencia entre las dos especies. [actualy V. glabrata H.B.K. as seen so abundantly in Ecuador is very easily distinguished in general aspect from V. 11toral1s!]. De existir on Venezuala, serla probablemente en Táchira y Zul1a, hasta donde pueden extenderse las poblaciones colombianas del Norte de Santander, on donde 1 . V. glabrata ha sido reglstrada."

Lopez-Palacios 3638 is a close match for the type illustration of V. 11toral1s, but his 3948 is the very widespread loosely fruit od form, while his 3623 is the very dense-flowered and -fruited form now passing as var. caracasana. He reports that the plants growing in his own garden and represented by his no. 3974 were $80-$ $100 \mathrm{~cm}$. tall. In a letter to me, dated Jamuary 16,1976 , he says: "Por correo le envés 5 ejemplares de Verbena litoralls colectados de una misma planta que yo tengo cultivada. Bste taxon es pol1mórfico y variable no sblo en la población sino en la misma planta, como Ud. podrá observar; en hojas y en espigas la variacion es grande. Yo of en Herb. Willdenow el tipo de la var. caracasana, pero en ml concepto todo ello es simplemente $\nabla$. litoralis. Natur almente esto es una cosa subjetiva y se deba a mi formación, influ1da por las escuelas europeas (Holandesa y Alemana) que tienen un criterio muy amplio de la especie. Naturalmente el dibujo de HBK 8610 muestra un estadio de crecimiento y por tanto no puede registrar todas las variaciones de la especie." He suggests that his 4161 may be a form of $\nabla$. brasiliensis Vell., and this 1s, indeed, very possible. It is also most probable that these two species hybridize when growling in close proximity, as they often do. His no. 4302, from the Galapagos islands, is described as "hierba de hojas medianas, espigas congestas luego alargadas".

Walker (1976) reports for V. I1toral1s the vernacular name, "hime-kuma-tsuzura" [-small delicate V. officinalis] on Oldnawa. Witham collected the species at 1000 m. altitude in Hawail, describing it as a "tough perennialn with blue flowers. Tovar Serpa (1975) records the vernacular name, "wirwena", for it in Peru. The Degeners \& Pekelo (1975) list the names, "ha'uöw" " "oi", and "owl", in Hawa11; Thomas (1969) calls 1t the "coast verbena".

Gibbs (1974) reports that in what he calls "Verbena arborea" cyanogenesis is absent from the leaves and syringin 18 absent from the stems. It 18 not definitely known if he refers here to $\nabla$. IItoralls or to Petrea arborea, for both of which taxs the name "Verbena arborea" has in the past been used in literature. Hartwall (1971) reports that in Mexdco V. litoralis is called "verbena del campo" and that the twigs are used to make a decoction drunk in the treatment of internal tumors. Krapovickas and his associates report its use in Salta, Argentina, "para golpe, paes sangre". Krapovickas, Schinint, \& Gons 2102 28440 represents the densespiked form of the species.

The W1dgren s.n. [1845], distributed as V. 11toralis, actualy 
1s V. alata Sweet, while Lechler s.n. [Valdivia], Leyboldt s.n., and Montz 2289 are V. bonariensis I., Fabris \& Marchionni 2392

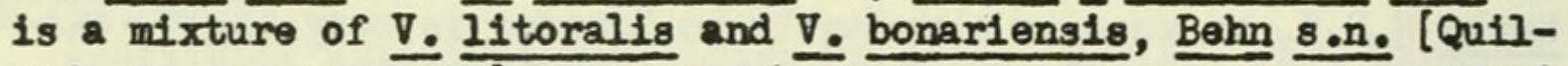
pue, 22 January 1931], Bougere 14, 1091, \& 1099, C. A. Brown 1008, 2309, 2381, \& 18610, Bymum, Ingram, \& Jaynes s.n. [Houma, Apr. 23, 1933], 1. Chaney 171, Claycomb 8.n. [June 13, 1942], Helnrichs 65, K1rby 160, D. K. Lowe 31, Meebold 27224 \& 27240, Montz 637, J. A. koore 5200, Neger s.n. [1893-96], Robinette 239, Rockett 125, Roivainen 3054, and Stutzenbaker 205 are V. brasiliensis Vell., Heyde \& Lux 3019 is V. carolina L., O. Bachtien 185 is XV. derment Moldenke, Claycomb s.n. [April 15, 1943] is V. halei Small, C. A. Brown 18767, Herb. Herter 81713, Herter 269, and Thibodeawx 236, $260,284,297,321$, \& 417 are v. montevidensis spreng., J. Taylor

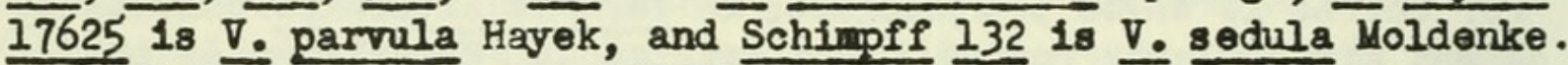
Additional oftations: LOUSIUNA: Terrebonne Par.: Whurzlow s.n. [Mav 5, 1914] (Lv, Lv). IEXICO: Oaxaca: Pringle 4877 (Mu-1803). Veracruz: Kerber 311 (M1, Mu-1791). GUATEMALA: Guatemala: L. M. Andrews 507 (N). Santa Rosa: Heyde \& Lux $4370(\mathrm{Mu}-1790)$. HONDURAS: Cortes: Mol1na R. 21508 (W-2735773). NIGARAGUA: Estell: Molina R. 27244 (N,w--2735237). COSTA RICA: San Jose: J. Taylor 17446 (N). COLOMBIA: Arauce: Lopez-Palacios 3948 (Ld, N). Cundinamarca: Lbpez-Palacios 3623 (Ld, N), 3638 (Ld, N); LbpezPalacios \& Jaramillo Mej1a 3674 (Ld, N). Magdalena: Romero-Castañeda $10668(\mathrm{~N})$. VENEZUETA : Aragua: Vogl 938 (Mu, Mu, Mu). Mérida: Oberwinkler \& Oberwinkler 12196 (Mu). Miranda: P1ttier 442 (Mu). ECUADOR: Carchi: Íbez-Palacios 4040 (Ld). Chimborazo: Collector undetermined s.n. [September 1858] (Mu-1105). EI Oro: Lbpez-Palacios 4100 (Ld). Guayas: Eggers $\mathrm{H}_{4372}$ (Mu-3882). Imbabura: Ibpez-Palacios 4072 (Ld). Loja: I6pez-Palacios 4161 (Ld). Pichincha: I6pez-Palacios 4196 (Ld), 4220 (Ld), 4332 (Ld). GALAPAGOS ISIANDS: Chatham: Schimpif 142 (Mn); Werff 2183 [1483] (Ld), 2186 [1486] (Ld). Narborough: ISpez-Palacios 4302 (Id). PERU: Cuzco: Plowman \& Davis $4889(02)$. BRAZIL: Minas Gerais: Irwin, Harley, \& Onishi 28721 (W-2759077). Rio de Janeiros Pabst 7372 (Mu). BOLIVIA: Ia Paz: M. Bang 204 (Mu-1788). PARAGUAY: Pedersen 8625 (N); T. Rojas 1889 (Nu). CHILE: Valpara1so: Behn s.n. [14 Decbr. 1930] (Mu); 0. Buchtien 8.n. [18.X.1895] (Mu-1838). Province undetermined: Dessauer $\mathbf{8 . n _ { 0 }}$ [Chile, VI-IX87] (Mu); Frömbling s.n. [Chil1, 1886] (Kh-1789). ARGENIINA: Ju fw: Schinini, Quarin, Arbo, \& P1re 10259 (Id). Salta: Krapovickas, Schinini, \& Gonzalez 28440 (Ld). San Juan: Fabris \& Marchionnt 2392, in part (Mu) . Santiago del Estero: Iullo 4 (Ut-220576B); Pierott1 "h" [6-II-1944] (Ut-330535B). SOUTH AFRICA: Transvaal: Meebold 12839 (Mu); Scheepers 334 (Mu); Schlie- 
ben 7691 (Mu). MARIANAS ISLANDS: Sa1pan: B. C. Stone 5233 (K1).. AUSTRALIA: Queensland: M. S. Clemens 42170 (Mi); Meebold 7818 (Ku). HATAIIAN ISLANDS: Hawa11: W1 tham 1723 (Sd-83745). Kavai: Herbst 2296 (N). Oahu: Meebold 830L (Mu); Schmer s.n. [9/13/69] (LC). CULTIVATED: Brazil: Hatschbach \& Kummror 35764 (Ld). Germany: Herb. Kunmer s.n. [Hort. bot. Monac. 1839] (Ku-1248). Venezuels: Blanco $110(N)$; Lopez-Palacios 3974 (Ac, Gz, Mu, Tu).

VERBENA LITORALIS var. ALBIFLORA Moldenke

Synomyr: Verbena littoralis var. albiflora Moldenke ex Hinton \& Rzedowsk1, Anal. Bsc. Nac. Cienc. Biol. 21: 111. 1975.

Additional b1bliography: Moldenke, Phytolog1a 28: 252, 432, \& 438. 1974; Hinton \& Rredowsid, Anal. Esc. Nac. Clenc. B1ol. 21: 31 \& 11l. 1975; Soukup, Blota 11: 19. 1976; Moldenke, Phytologia 36: 47.1977 .

VERBENA LITORALIS var. CARACASANA (H.B.K.) Moldenke

After extensive field and herbarlum studies, including an examination of the type collection, L6pez-Palacios has shown that this taxon cannot be distinguished from typical V. litoralls H.B.K. All ay previous notes in this series under this heading should therefore be transferred to typical V. 11toralis.

VERBENA LITORALIS f. MAGNIFOLIA Moldenke, Phytologia 36: 51-52. 1977.

B1bliography: Moldenke, Phytolog1a 36: 33 \& 51-52. 1977.

C1tations: BCUADOR: Napo: L6pez-Palacios L188 (z-type).

VERBENA LOBATA Vell.

Add1tional bibliography: Buek, Gen. Spec. Syn. Candoll. 3: 494 \& 495. 1858; Noldenke, Phytolog1a 30: 154. 1975.

The Hatschbach HH.14883 and Herb. Brad. 48010 , distributed as V. lobsta, actually represent var. sessilis Moldenke.

Additional citations: BRAZIL: Minas Gerais: Dasen 242 (Mn-3998). R10 de Janeiro: A. Castellanos 25682 [Herb. FEEMA L520] (Id). R10 Grande do Sul: Bormatiler 602 (1u-4295).

VERBENA LOBATA var. HIRSUTA Moldenke

Additional bibliography: Koldenke, Phytologia 28: 253. 1974. The corollas are sald to have been "lilac" in color when fresh on Hatschbach 35664 .

Additional citations: BRAZII: Parana: Hatschbach 35664 (Ld).

VERBENA LOBATA var. SESSILIS Moldenke

Additional bibliography: Moldenke, Phytologia 28: 355.1974.

The corollas on Hatsohbrch HH.14883 are sald to have been

"dark-11lac" in color when fresh, and this collector encountered the plant in "brejo" (sedge meadow), flowering in October. It was distributed in some herbaria as typical $\nabla$. lobata Vell.

Additional c1tations: BRAZIl: Parand: Hatgchbach HH.14883 [Herb. 
Brad. 48010] (Ku).

VERBENA LONGIFOLIA Mart. \& Gal.

Add1tional synonyu: Verbena longifolla H.B.K. ex Koldenke, Phytologia 36: 47, in syn. 1977.

Additional bibliography: Buek, Gen. Spec. Syn. Candoll. 3: 495 . 1858; Noldonke, Phytologia 23: 296 (1972), 34: 252 (1976), and 36: 47 \& 145.1977.

The corollas are said to have been "white to pale-pink" on Ernst 2355.

Additional citations: MEXICO: Oaxace: Ernst 2355a (Mi).

VERBENA LONGIFOIIA f. ALBIFLORA Moldenke

Additional bibliography: Moldenke, Phytologia 28: 253 (1974), 34: 252 (1976), and 36: 145. 1977.

Lartinez Calderon refers to this plant as an anmual herb which he encountered at $5 \mathrm{~m}$. altitude in "øuelo arcilloso-arenoso in acahual" and which he misidentified and distributed as V. carolina L. The Ernst $2355 \mathrm{a}$, cited under typical V. longifolia (above), is said to have come from a population th white to light-pink flowers so it may, in part, at least, also ropresent this form. (N).

Additional citations: MEXICO: Veracruz: Martínez Calderón 1352

VERBENA LUCANENSIS Moldenke

Additional bibliography: Moldenke, Phytologia 23: 297. 1972; Soukup, Biote 11: 19. 1976.

VERBENA MACDOUGALII Heller

Additional \& emended billiography: Bolkh., Grif, Matvej., \& Zakhar., Chrom. Numb. Flow. PI., imp. 1, 717. 1969; G. W. Thomas, Tex. P1. Ecolog. Summ. 78. 1969; Fong, Trojánkova, Trojanek, \& Farnsworth, Lloydia 35: 147. 1972; Bolkh., Grif, Matrej., \& Zakhar., Chrom. Numb. Flow. PI., imp. 2, 777. 1974; R. D. Gibbs, Chemotax. Flow. P1. 3: 1753 \& 1754 (1974) and $4: 2295.1974 ;$ D. S. \& H. B. Correll, Aquat. \& Wetland PI. SW. U. S., imp. 2, 2: 1397, 1399-1400, \& 1775. 1975; Kooiman, Act. Bot. Neer1. 24: 464. 1975; A. L. Moldenke, Phytologia 31: 415. 1975; Moldenke, Phytologia 30: 154 (1975) and 36: 145. 1977.

The Spellenbergs encountered this plant "along dirt road with grasses, in Douglas fir, PInus, Quercus, and Holodiscus" association. Pinkava and his associates found it along roadsides in ponderosa pine forests - a habitat apparently identical to that in which my wife, my son, and I saw it in great abundance and which seems to be its favorite habitat. Higgins reports finding it in sandy soil of "short-grass prairie community", in sandy soil of "spruce-fir-pine community", and in "coarse sandy to gravelly soil In mountain brush and mixed evergreen communit ty and aspen scattered in patches". Dzlekanowski and his associates observed it in "very rocky yellow pine forests".

The corollas are said to have been "violet, fading to blue" on 
Spellenberg \& Spellenberg 2082. Thomas (1969) calls the species the "Macdougal verbena".

Gibbs (1974) reports cyanogenesis absent in the leaves of $\nabla$. macdougalii and the Ehrlich test negative, but syringin is doubtfolly present in the stems.

Material has been misidentified and distributed in some herbaris as V. hastata var. scabra koldenke.

Additional citations: COLORADO: Archulete Co.: C. F. Baker s.n. [Arboles, 7-10-99] '(Mh-3912). NEW MEXICO: Otero Co.: Spellenberg \& Spellenberg 2082 (N). Lincoln Co.: Higging 8604 (N). San K1guel Co.: H1ggins 8881 (N). Taos Co.: H1ggins, H1ggins, \& Rook 10040 (N); Waterfall 12250 (M1). Yavapai Co.: H. H. Pasby 780, in part (Mu). ARIZONA: Apache Co.: Lehto, NcGill , Nash, \& Pinkava 11506 (W-2734642); P1nkava, Lehto, \& Reeves P.12352 (N). Cocontno Co.: Dzlekanowgk1, Dunn, \& Bennett 2395 (N).

VERBENA MACDOUGALII 1 . ALBIFLORA Moldenke

Additional bibliography: Moldenke, Phytolog1a 28: 253, 254, \& 431. 1974 .

\section{VERBENA MALMII Moldenke}

Additional bibliography: Moldenke, Phytologia 23: 298. 1972; Troncoso, Darwiniana 18: 311 \& 412. 1974.

Hatschbach describes this species as growing from a xylopodium. He found it on dry campos, flowering in December, and the corollas on his no. 35553 are satd to have been "lilac" in color when fresh.

Additional c1tations: BRAZIL: Paraná: Hatschbach 35553 (Ld).

VERBENA XARITTMA SmaII

Additional synonym: Verbena maritima Sm. ex Norman, Fla. Scient1st 39: 30.1976.

Additional bibliography: M. F. Baker, Fla. Wild Fls., ed. 2, imp. 1, 188. 1938; Ayensu, Rep. Bndang. \& Threat. PI. Spec. 98 \& 129. 1974; Moldenke, Phytologia 28: 254, 451. \& 464 (1974) and 34: 248 \& 279. 1976; M. F. Baker, Fla. Wild Fls., ed. 2, imp. 2, 188. 1976; Long \& Lakela, F1. Trop. Fla., ed. 2, 741 \& 961. 1976; Norman, Fla. Scientist 39: 30. 1976; Moldenke, Phytologia 36: 142. 1977.

Ayensu (1974) has officially listed this as an endangered or threatened species. With the rapidity of the commercialization of the Florida beaches, the survival of this species, limited to that specialized habitat, is certainly in great doubt.

Churchill has encountered V. maritima in pine flatwoods on oolitic limestone and on the Tee side of dunes, as well as in dune hollows, in flower and fruit in March and June. Norman (1976) calls it the "seaside verbena" and justifiably refers to it as already "rare".

Add1tional c1tations: FLORIDA: Brevard Co.: Curt1ss 1963* (Mu1545). Broward Co.: Meebold 27688 (Mu). Dade Co.: J. A. Church- 
111 s.n. [12 March 1956] (In-204149). Martin Co.: J. A. ChurchIII s.n. [18 June 1968] (Ln--225090). Long Key: J. K. SmaI1 8123 (Mu)

VERBENA MARRUBIOIDES Cham.

Additional bibllography: Buek, Gen. Spec. Syn. Candoll. 3: 495. 1858; Moldenke, Phyțologia 30: 154. 1975; Soukup, Biota 11: 19. 1976.

Recent collectors have encountered this plant along roadsides on campos and in "campo com pequeño banhado". The corollas are said to have been "red (5P6/8)" on Lindeman, Irgang, \& Valls ICN. 8805 and "blue-purple (1OPB5/8)" on Lindeman \& Haas 2459 .

Reineck \& Czermak 21 is a mixture of V. marrubioides and V. humifusa Cham.

Additional cltations: BRAZIL: Parana: Lindeman \& Haas 2459 (Ld). Rio Grande do Sul: Iindeman, Irgang, \& VaIl 3 ICN.8805 (Ut-320456); Reineck \& Czermak 2I, in part (Mu).

VERBENA MEDICINALIS ROJas

Additional \& emended bibliography: Krapovickas, Bol. Soc. Argent. Bot. 11, Supl. 269. 1970; Moldenke, Phytologia 30: 154-155 (1975) and 31: 388. 1975.

VERBENA MEGAPOTAMICA Spreng.

Additional synonymy: Verbena phlogiflora $\beta$ macilenta Cham. ex Buek, Gen. Spec. Syn. Candoll. 3: 495. 1858.

Additional \& emended bibliography: Loud., Hort. Brit., ed. 2, 552. 1832; Buek, Gen. Spec. Syn. Candoll. 3: 495. 1858; Bolkh., Grif, Matrej., \& Zakhar., Chrom. Numb. Flow. P1., imp. 1, 715

(1969) and imp. 2, 715. 1974; Moldenke, Phytologia 30: 155 \& 178 (1975) and 36: 47. 1977.

The label on Krapovickas \& Cristobal 28956 bears the statement "en campos pantanosos, erecta, flores amarillas" - if the corolla color given here is correct this represents a remarkable undescribed color-form, but it seems more probable to me that it represents a mistake in memory or transcription.

The Hort. Parag. 11793 and T. Rojas 3406, distributed as V. megapotamioa, actually are V. incisa Hook., while Duarte 6309, Herb. Brad. 16885 \& 22512, Pabst 6093, and E. Pereira $62 \overline{66}$ are V. phlogiflora Cham.

Additional citations: ARGENTINA: Corrientes: Krapovickas \& Cristóbal 28956 (Ld).

VERBENA MEGAPOTAMICA Spreng. $x \boldsymbol{V}$. PULCHELLA Sweet

Additional bibliography: Moldenke, Phytologia 28: 255, 45l, \& 464. 1974 .

VERBENA MENDOCINA R. A. Phil.

Additional \& emended blbliography: Bolkh., Grif, Matvej., \& Zak- 
har., Chrom. Numb. Flow. P1., 1mp. 1, 715 \& 717 (1969) and 1mp. 2, 715 \& 717. 1974; Moldenke, Phytologia 30: 155. 1975.

VERBENA MENTHAEFOLIA Benth.

Additional bibliography: Buek, Gen. Spec. Syn. Candoll. 3: 495 \& 496. 1858; G. W. Thomas, Tex. P1. Ecolog. Summ. 78. 1969; Moldenke, Phytologia 28: 355 \& 362 (1974) and 30: 159. 1975; Hinton \& Rzedowsk1, Anal. Bsc. Nac. Cienc. B10l. 21: 31 \& 21. 1975; Moldenke, Phytologia 36: 145. 1977.

Recent collectors have encountered this plant on rockg hills with thin gravelly soil and oak-pine grassland cover. Mears found it growing in association with Cassia, Kimosa, Juniperus, Solanum, Cuphea, Quercus, Indigofera, and Phoradendron. In Baja California it is reported by Moran as "occasional", "abundant in roadside depressions", "common in roadside ditches", and "locally common in several places on dry open southeast slopes", at 10 to 200 meters altitude, describing it as a "decumbent bush" or "prostrate". The corollas are described as having been "blue" on Moran 16643 \& 18675, "blue-v1olet" on Moran 16098, 18563, \& 21824, "purple" on Witham 783, and "light-blue, with white center" on Moran 22459. Thomas (1969) calls it the "mintleaf ver bena", a singularly inappropriate name since its leaves do not resemble those of any typical mint with which I am familiar. The Baja California material ascribed to this species needs to be more carefully compared to V. comonduensis Moldenke, a closeIy related taxon.

Additional citations: CALIFORNIA: San Diego Co.: R. V. Moran 16098 (Sd-71707); Spenoer 8.n. [4.25.1916] (Mu-4318); Witham 783 (Sd-79855). WEXICO: Baja California: R. V. Moran $1 \overline{6643}$ (Sd-73069), 18563 (Sd-80229), 18675 (Sd-80255), 21824 (Sd91272), 22459 (Sd-91088). Feder2l District: Barkley \& Rowell 7464 (Ln-166003). Hidalgo: Mears 259d (Ln-222126), $\overline{326 \mathrm{~d}(\mathrm{Ln}-}$ 222197). Méxdco: Pringle 8534(Mu-3989). Zacatecas: Taylor \& Tsylor 6230 (W-2734032).

VERBENA MICROPHYLLA H.B.K.

Additional bibliography: Buek, Gen. Spec. Syn. Candoll. 3: 495. 1858; Moldenke, Phytologia 30: 155. 1975; Soukup, B1ota 11: 19. 1976 .

Schultes has placed an interesting note on the $\underline{M}_{0}$ Wagner 8.n. [Sept. 1858] sheet at Munich: "Verbena erinoidi Lam. proxdma sed 1pse vix videtur. An V. multifida R. \& Pavon quae a Schanero Verbenae erino1di subjungitur".

Legname \& Vervoorst refer to V. microphylla as a "prostrate hemicryptophyte" and encountered it in "terreno arenoso-arcilloso" - the corollas on their no. 101 were "palo-11lac" when fresh. Additional citations: ECUADOR: Chimborazo: Schimpef 720 (Ka); M. Wagner 8.n. [Sept. 1858] ( $(\mathbf{u}-1104)$. Cotopard: M. Wagner s.n. [October 1858] (uu-1262). Province undetermined: 产. Wagner $\overline{\text { s.n. }}$ 
[Tacunga, Octob.-Nov. 1858] (Mu-1263). PERO: Cuzco: W. Hoffmann 307 (Ku). BOLIVIA: La Paz: 0. Buchtien 1102 (Mu); $\overline{\mathrm{K}}$. Graf 453 (N). Oruro: Troll 2919 (Mu). Potos1: Fiebrig 2613 (Mu4088). Province undetermined: K. Graf 599 [Taurichamb1] (N). ARGENIINA: Catamarca: Legname \& Vervoorst 101 (N). Jujuy: Cabrere, Ancibor, Ré, Tello, \& Torres 15474 (Nu); Ellenberg 4259 (Id), 4261 (AC). Province undetermined: Princess Therese of Bavaria $\underline{282}(\mathrm{Mu})$.

VERBENA MINUTIFLORA Briq.

Additional bibliography: Moldenke, Phytologia 28: 356 \& 383 (1974) and 36: 36 \& 123. 1977.

In addition to the months previously reported by me, this plant has been collected in fruit in March and October. It has been described by Lindeman \& Haas as an almost leafless shrub, $1.5 \mathrm{~m}$. tall, and the corollas on their no. 3010 are said to have been "purple" when fresh. On Iindeman ICN.9446 the collector notes "arbusto de $1.70 \mathrm{~m} ., 1.5 \mathrm{~cm}$. diam., corola roxa 10PB7/6", and it was encountered by him in a "pequerio banhado quase seco".

Davidse and his associates report that in Santa Catarina it is used in the treatment of stomach and digestive ailments.

Material of V. mimutiflora has been misidentified and distributed in some herbaria as V. alate Sweet.

Additional citations: BRAZIL: Parana: Hatschbach 37374 (Id); Lindeman \& Hass 3010 (Ws). Rio Grande do Sul: Lindeman ICN.9L46 (Ut-320459). Santa Catarina: Davidse, Ramamoorthy, \& Vital 11089 (Ld). ARGENTINA: Toledo Island: Ibarrola 739 (Ut-330572B).

xVERBENA MOECHINA Moldenke

Additional synonyul Verbena moenchina Moldenke ex R. A. Davidson, State Univ. Iowa Stud. Nat. Hist. 20 (2): 77 , sphalm. 1959.

Additional bibliography: R. A. Davidson, State Univ. Iowa Stud. Nat. Hist. 20 (2): 77. 1959; Cooperrider, State Univ. Iowa Stud. Nat. Hist. 20 (5): 70. 1962; Moldenke, Phytologia 28: 356, $386,387,429, \& 465$ (194), 34: 249 (1976), and 36: 29 \& 47 . 1977.

Tans encountered this hybrid along roadsides and in an abandoned quarry on limestone gravel in association with native prairie plants such as Asclepias verticillata, Andropogon gerardi, Eragrostis spectabilis, Kuhnia eupatorioides, Ratibida pinnate, Solidago nemoralis, and Verbena stricta, with Verbascum and Ambrosia Invading. Davidson (1959) records the hybrid from Loulsa and Nuscatine Counties, Iown, where he found it to be "infrequent" in dry sandy soil.

The Herb. Zuccarint 8.n. [Hort. bot. Monac.] collection, cited below, is a mixture with V. stricta Vent.

Additional citations: WiscoNSIN: Rock Co.: Tens 1431 (Ts, Ts, 
Ts). MISSOURI: Reynolds Co.: Meobold 25420 (Mu). CULTIVATED: Germany : Herb. Zuccarint s.n. [Hort. bot. Monac.] (Mu-375, Mu376).

VERBEIT YONACENSIS Moldenke

Additional bibliography: Moldenke, Phytologia 28: 356, 394, \& 451 (1974), 30: 133 (1975), and 34: 270. 1976; L6pez-Palacios, Revist. Fac. Farm. Univ. Los Andes 17: 50. 1976; Moldenke, Phytologia 36: 40. 1977.

Lopez-Palacios refers to this plant as an "hierba rastrera de unos 30 cms. Flores rosadas" and found it being cultivated at 1650 meters altitude, flowering in August.

Additional citations: CULTIVATED: Colombia: Lopez-Palacios 3618 (Ld, N), 3862 (Tu); Lopez-Palac108 \& Idrobo 3833 (Ac).

VERBENA MONTEVIDENSIS Spreng .

Additional \& exended bibliography: Buek, Gen. Spec. Syn. Candoll. 3: 495. 1858; Bolkh., Grif, Matvej., \& Zakhar., Chrom. Mumb. FIow. PI., 1mp. 1, 717 (1969) and 1mp. 2, 717. 1974; Moldenke, Phytologia 30: 155 (1975), 31: 377 (1975), and 36: 137. 1977.

The corollas on Ferreira 98, Hatschbach 35653, and Kummrow 764 are sald to have been "Illac" in color when fresh, on Schinint \& Carnevali 10471 they were "purple", and on Fiebrig 4635, Herb. Brad. 22518, Pabst 6146, and E. Pereira 6319 they were "violet".

Ferreira found the plant growing in "orla de brejo". Others have encountered it on high or marshy campos, in rough grassland, along roadsides, on headlands of ricefields and sugarcane fields, in bottomland soll, and in "brejo" (sedge meadows). Muhammad refers to it as "an erect perennial herb, infrequent in open fields maintained by fire", while Urbatsch found it "in roadside and railway right-of-way, aquatic marsh, and dryland habitats".

The corollas on Schinint \& Cristobal 9707 were "violet" in color when fresh, those on Quarln, Schininl, \& González 2460 were "purplen", those on Krapovickas, Cristobal, \& Schinini 26513 were "white-lilac", and those on Pedersen 9816 were "whiten.

Lindeman and his associates encountered this plant on a "campo estilo pomar com árvores balxas de espinilo Acacia caven ${ }^{n}$ and say on the label of their no. 8468 "corola $5 \mathrm{RP} 8 / 4$, callee em bota 8 5RP5/4". The vernacular name, "quina", is reported by Kummrow. Pedersen found the plant in flower and fruit in April.

Additional c1tations: IOUISIANA: Calcasieu Par.: Thibodeaux 260 (Lv). Cameron Par.: Thibodeaux 236 (Lv). East Baton Rouge Par.: C. A. Brown 18767 (Iv). Jefferson Dav1s Par.: Thibodeaux 417 (IV). Lafayette Par.: Thtbodeaux 297 (Lv), 321 (Iv). Saint Landry Par.: Thtbodeaux 428 (Lv). Tangipahoa Par.: Yuhammad 259 (Lv); Urbatsch 1938 (Lv). Vermslion Par.: Thibodeaux 284 (Lv). BRAZII: Parank: Dusén 10856 (Mu); L. F. Ferreira 98 (Id); Hatschbach 35653 (Id); Kummrow 764 (Tu). Rio Grande do Sul: Iindeman, Irgang, \& Valls ICN.8468 $(\mathrm{Ut}-320457)$. Santa Catarina: Pabst 6146 
[E. Pereira 6319; Herb. Brad. 22518] (Mu). PARAGUAY: Fiebrig $4635($ Mu-4144). URUGUAY: Herter 269 [Herb. Herter 81713] (1/u). ARGENINA: Corrientes: Krapovickas, Crist6bal, \& Schinini 26513 (Id); Pederven 9816 (N); Quarin, Schinini, \& González 2460 (Ld); Schinini \& al. 11864 (Ld); Schinini \& Carnevali 10471 (Id) s Sohtnini \& Crist6bal 9707 (Id). Kisiones: Montes 14719 (N), 27576 (N).

VERBENA MONTICOIA Moldenke

Additional bibllography: Hocking, Bxcerpt. Bot. A.26: 6. 1975; Moldenke, Phytologia 30: $155(1975)$ and 31: 384.1975.

VERBENA MULTICAULIS Raf.

This taxon is probably the same as V. simplex var. eggert1 Moldenke. All previously published notes in this serles under this heading should be transferred to that variety.

VERBENA NANA Moldenke

Additional bibliography: Moldenke, Phytologia 30: 155. 1975.

The corollas on Fiebrig 4371 are said to have been "violetrose" when fresh.

Additional citations: PARAGUAY: Fiebrig 4371 (Ku).

VERBENA NEOMEXICANA (A. Cray) Small

Additional symonymy: Verbena neomexicana var. neomexdeana [A. Gray a aud Thomas, Tex. P1. Ecolog. Summ. 78. 1969.

Additional \& emended blbliography: G. W. Thomas, Tex. PI. Ecolog. Summ. 78. 1969; Bolkh., Grif, Matrej., \& Zakhar., Chrom. Mumb. Flow. P1., imp. 1, 17 (1969) and imp. 2, 717. 1974; E. H. Jordan, Checklist Organ Pipe Cact. Natl. Mon. 7. 1975; Moldenke, Phytologia $30: 138,155-156, \& 180$ (1975), 31: 378 (1975), 34: 252 \& 279 (1976), and $36: 124$ \& 158. 1977.

Semple refers to this plant as "rare, in small clumps in dry stream bed". Mrg. Jordan (1975) calls it the "New Mexican vervain" and Thomas (1969) names it the "New Mexico virbenan. Urbatsch and his associates aver that it is "uncomon in sandy soil" in Baja California.

Material of this species has been misidentifled and distributed in some herbaris as V. graclils Desf. or V. plicata Greene. On the other hand, the Spellenberg \& Spellenberg 3984, distributed as typical V. noomexlcana, seems better placed as var. hirtella Perry, while Reeves R.I131 and Wentworth 1061 are var. xylopoda Perry, C. A. Brown 7409 and Monte 2485 are xV. alleni Moldenke, Taylor \& TayIor 6230 18 V. menthrefolla Benth., Hess \& Stickney 3406 and Higgins 9228 are V. perennis Wooton, S. Walker $76 \mathrm{H} 37$ is V. pinetorrm Moldenke, and Meobold 26696 is V. racemose Eggert.

Additional c1tations: TEXAS: Brewster Co.: Semple 357 (W2732729). ARIZONA: PLma Co.: J. A. Charchill s.n. [7 April 1972] (In-235702). Santa Cruz Co.: Foeves R.1198 (N). MaxICO: Baja 
California: Urbatsch, Clark, \& Betkouski $\underline{1}_{4} 36$ (Id). Coahu1la: Barkley, Wobster, \& Rowell 7189 (Ln-189725).

VERBENA NEOMEXICANA var. HIRTELLA Perry

Additional bibliogrephy: G. W. Thomas, Tex. P1. Ecolog. Summ. 78. 1969; Moldenke, Phytolog1a 30: $138 \& 156$ (1975) and 34: 252. 1976.

Arnold found this plant growing on "steep gravelly hills and creek beds" in Coahuila. In Chimuahua the Spellenbergs encountered the plant "on grassy knolls with mostly ocotillo, creosotebush, Yucca torreyi, sotol, and Hecyotis rubra". In Baja California Moran found It "occasional in d1sturbed roadside so1l" and "occasional on sandy flats", at altitudes of 575-1600 meters. Correll \& Rollins encountered'it "on gravel knolls along roadsides" in Texas.

The corollas are said to have been "deep-blue" on Moran 21749 , "blue" on Correll \& Rolling 23652 and Moran 20727, "blue-violet" on Moran 20748 and Spellenberg \& Spellenberg 3984, and "lavender" on Moran 16893; they were also "blue" on Henrickson 5944

Other recent collector have found $\mathrm{V}$. neomexicana var. hirtella growling in "calcareous gravel in chaparral on very steep slopes of ilmestone sierra", "In calcareous gravelly soil in matorral desertico microfilo on limestone slopes and limestone-conglomerate fan", "In rocky calcareous soll in crasirosulifollo espinosos 1zotal on steep slopes of metamorphosed shaly limestone", "In dark, sandy, grussy, gravelly loan on gentle slopes of extrusive igneous rock", "In sandy alluvium in matorral desertico inerme on gravel fans", in "calcareous gravelly soil in matorral con espinas laterales in canyons through limestone", "on rockg northeast-facing slopes", in "rock soll of matorral on steep slopes of igneous rocks with chaparral and encinares (oak woods) higher up", in "rocky reddish clay soll of deserts", and in "limestone outcroppings in open Chihuahnan Desert" ${ }^{n}$, in association with Yucca carnerosana, Agave parrasana, A. lecheguilla, Condalia warnocki1, Berberis trifoliolata, Mammillaria meiscantha, Opuntia rufida, 0. I1ndheimerl, Acacia rigidula, Viguiora stenoloba, Sagaretia wrighti1, Dasylirion, Quercus, Indleya, Kramer1a, Mimosa, kuhlenberg1a, Pimus, Larrea, Jatropha, Parthenium, Leucophyllum, Ptelea, Garrya, Juglans, Flourensia, Buddleia, Fouquieria, Nama, grasses, and mumerous anmals. Henrickson found it "Infrequent along highways".

Additional citations: TEXAS: Presidio Co.: Correll \& Rollins 23652 (N). MBXICO: Baja Californ1a: R. V. Moran 16893 (Sd-76990), $20727(\mathrm{Sd}-88938), 20748(\mathrm{Sd}-88937), 21749(\mathrm{Sd}-91271)$. Chithwama: A. A. Heller s.n. [April 6, 1897] (In-93653); Henrickson 7617 (Id); Johnston, Wendt, \& Chtang C. 10773b (Id); Speilenberg \& Spellenberg 3984 (N); W11son, Wilson, Johnston, \& Johnston 8510 (Ld). Coahuila: E. T. Arnold 32 (Te-68564); Henrickson 5944 (Id), 6132 (Id); Johnston, Wendt, \& Chiang C. 1028 Ld (Id), 10500c (Id), 11687 
(Ld). Nuevo León: Johnston, Wendt, \& Chiang C. 10235b (Ld). Zaa

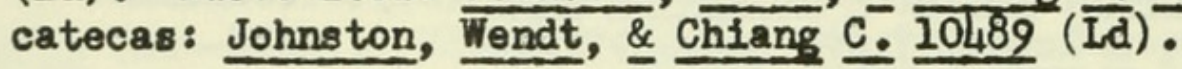

VERBENA NEOMEXICANA var. XYLOPODA PEIrY

Additional bibllography: G. W. Thomas, Tex. Pl. Ecolog. Summ. 78. 1969; Moldenke, Phytologia 30: 156 \& 180. 1975.

Recent collectors have encountered this variety on north-facing slopes with rock outcrops, calcareous stones and solls with scattered oaks, on rocky outcrops with Fouquieria, and in Cercocarpus breviflorus scrub on limestone bedrock.

Other collectors have found it growing in rocky linestone soil, in "sandy, grussy, gravelly loom in small creek canyons through extensive igneous rock", In "rocky soil in pastizal, badly degraded and in places invaded by shrubs", on "hill of igneous extrusives with partly volcanic ash red of red color", and in "grussy, gravelly, thin soil on rather stoep hills of extrusive igneous rocks", growing in association with Parthenium incamum, Lippia graveolens, Jatropha diolca, Acac1a neovernicose, Boutelous grac1lis, Larrea, Quercus, Pimus, and Pseudotsuga.

In Baja California Moran reports this variety "locally common on open upper south slopes", "scarce on ridges", "occasional in granitic soll on rocky hillsides", and "a small colong on dry rocky slopen", at altitudes of 1025-1240 meters. The corollas were "blue" on Moran 20983 \& 22170, "blue-Vlolet" on Moran 18264, "light-blue, paler in the center" on Moran 17658, and "purple" on Powell, Turner, \& Sikes 2479 .

The Wentworth collection cited below is a voucher for ecologic studies.

Additional citations: ARIZONA: Cochise Co.: Wentworth 1061 (N). Pinal Co.: Lehto, Hensel, \& Pinkara 11033 (W-2736741). Santa Cruz Co.: Reeves R.Il31 (N). MRXICO: Baja California: R. V. Moran 17658 (Sd-75054), 18264 (Sd-77109), 20983 (Sd-83866), 22170 (Sd-91462). Chimuahua: Chiang C., Wendt, \& Johnston 8311a (Id); Johnston, Wendt, \& Chiang C. 10524 (Id); Poẅell, Turner, \& Sikes 2479 (Id); Wilson, Wilson, Johnston, \& Johnston 8483 (Id). TamauI1pas: Kuiper \& Kuiper-Lapre M.15 (Ut-328637B).

VERBENA NIGRICANS Rojas

Additional \& emended bibliography: Krapovickas, Bol. Soc. Argent. Bot. 11, Supl. 269. 1970; Moldenke, Phytologia 30: 156 (1975) and $31: 388.1975$.

VERBENA NIVEA Moldenke

Additional synonymo: Glandularia nivea Mold. ex Moldenke, Phytologia 34: 274, in syn. 1976.

Additional bibliography: Moldenke, Phytologia 28: 357 (1974) and 34: 274.1976.

In addition to the months previously reported by me, this plant has been collected in fruit in February. 
The Legname \& Vervoorst 101, distributed as V. n1vea, actually is V. microphylis H.B.K.

VERBENA OCCULTA Moldenke

Additional bibliography: Moldenke, Phytologia 23: 376-377 (1972) and 34: 258. 1976; Soukup, Blota 11: 19. 1976; Moldenke, Phytologia 36: 148. 1977 .

Naterial of this species has been misidentifled and distributed in some herbaria as V. calcicola Walp. and V. clavata Fulz \& Pav.

Additional cltations: PERU: Arequipa: Princess Therese of Bavaria 281 (Mu).

VERBENA OCCULTA I. ALBA Moldenke

Additional bibliography: Moldenke, Phytologia 23: 377..1972; Soukup, Biota 11: 19. 1976.

VERBENA OCCULTA f. AURANTIAGA Moldenke

Additional bibliography: Moldenke, Phytologia 23: 377. 1972; Soukup, Biota 11: 19. 1976.

VERBENA OFFICINALIS L.

Additional synonymy: Verbena vulgaris follo variegato Breyn., Prodr. Fasc. Rar. P1., ed. 2, 2: 104. 1739.

Additional \& emended blbliography: Apul. Barb., Herb., ed. 1. 1480-1483; Anon., Dialogue des Créatures, 30th dial. 1482; Apul. Barb., Herb., ed. 2. 1528; Anon., Bastiment des Receptes fol. 59 vert. 154h; H. Bock [Tragus], Stirp. Max. Germ. 102. 2552; Dill. In Ray, Synop. Meth. Stirp. Brit., ed. 3, 236. 1724; L., Hort. Cliff., Imp. 1, 11. 1737; Breyn., Prodr. Fasc. Rar. P1., ed. 2, 2: 104. 1739; Strand in L., Amoen. Acad. 69: 449. 1756; Chomel, Abrég. Hist. P1. Usuel., ed. 6, 2 (2): 85-87 \& 251. 1761; Ginanni, Istor. Civ. Nat. Pinet. Ravenn. 177. 1774; Chomel, Abrøg. Hist. P1. Usuel., ed. 6 nov., 313 \& 637. 1782; F. Hernandez, Hist. Pl. Nuev. Espaff., ed. 1, 1: 139 \& 439 (1790) and ed. 1, 3: 3 \& 486. 1790; R. A. Salisb., Prodr. 71. 1796; Chomel, Abrég. H1st. P1. Usuel., ed. 7, 1: 495 (1803) and ed. 7, 2: 488. 1803; Stokes, Bot. Mat. Med. 40-41. 1812; A. Rich., Bot. Méd. 1: 242-243. 1823; Dierbach, Arzneimit. H1ppok. 85 \& 270. 1824; A. R1ch. [transl. G. Kunze], Med. Bot. 1: 381 (1824) and 2: 1302. 1826; G. Don in Loud., Hort. Brit., ed. 1, 247 (1830) and ed. 2, 247. 1832; Loud., Hort. Brit., ed. 2, 552. 1832; A. Dietr., Handb. Pharmaceut. Bot. 124 \& 412 . 1837; D. Dietr., Taschenb. Arzneiger. Deutschl. 58 \& 262. 1838; G. Don in Loud., Hort. Brit., ed. 3, 247. 1839; Spach, H1st. Nat. Veg. Phan. 9: 237. 1840; Webb in Hook., N1ger F1. 161. 1849; Anon., Chroniqueur du P6rigord 120. 1853; F. Lenormant, Bull. Sic. Bot. France 2: 315-320. 1855; Schnitzlein, Iconofr. Fam. Nat. 2: 137 Verbenac. [2] \& 137, fig. 4-22 \& 30. 1856; Buek, Gen. Spec. Syn. Candoll. 3: 495 \& 496. 1858; Symphor Vaudors, Lettr. Vieux Laboureur 88. 1867; J. Cousin, Secr. Mag. 1868: 7, 37, \& 45. 1868; Chenaux, Le Diable \& Ses 
Cornes 53 \& 54. 1876; Anon., Rev. du Tarn 1877: 39. 1877; Franch., Nouv. Arch. Mus. Hist. Nat. Paris, ser. 2, 6: 112 [P]. David. 1: 232]. 1883; Strobl, Oesterr. Bot. Zeitschr. 33: 406. 1883; Kuntze, Rev. Gen. P1. 2: 510. 1891; J. Camus, Récept. Franç. in Bull. Soc. Syndic. Pharmac. Côte-d'Or. 10. 1892; J. Felller, Bull . Folklore 2: 105--109. 1893; Nairne, Flow. PI. West. India 249. 1894; Van Tieghem, Blem. Bot., ed. 3, 2: 373. 1898; Bidault, Superet. Méd. Mor $\operatorname{van}$ 36. 1899; Diels, FI. Cent.-China 547. 1902; Anon., Rev. Tradit. Populaires 1904: 162 (1904) anf 1905: 160 \& 296. 1905; Druce \& Vines, Dill. Herb. 78. 1907; Rolland, Fl. Populaire 8: 38-43. 1910; Gilg in Bngl., Syllab. Pflanzenfam., ed. 7, 314, fig. $413 \mathrm{C}$. 1912; Loes., Verh. Bot. Ver. Brand. 53: 74. 1912; Gilg In Engl., Syllab. Pflanzenfam., ed. 8, 318, fig. $413 \mathrm{C}$ (1919) and od. 9 \& 10, 339, P1g. 418C. 1924; Robledo, Bot. Med. 267. 1924; Krause in Just, Bot. Jahresber. L4: 1172. 1926; Fedde in Just, Bot. Jahresber. W4: 1534. 1927; Freise, Bol. Agric. Sto Paulo 34: 480 \& 494. 1933; Gunther, Herb. Apui. Barb. [16v], [35v], 106, 128, 129, \& 133. 1935; E. D. Merr., Trans. Am. Phil]. Soc., ser. 2, 24 (2): [Comm. Lour.] 331 \& 444. 1935; Diels in Engl., Syllab. Pflanzenfam., ed. II, 339, f1g. 432C. 1936; F. Hernandez, H1st. PI. Nuev. Españ., d. 2, 653 \& 674. 1943; Ro1, Atl. Pl. MGd. Chin. [Mus . Heude Bot. Bot. Chin. 8: ] 96. 1946; Hatta, Kubo, \& Watanabe, List Med. PI. I4. 1952; Sonohara, Tawada, \& Amano [ed. E. H. Walker], FI. Okin. 132. 1952; Pételot, Arch. Recherch. Agron. \& Past. Viet. 18: [253]. 1953; Pételot, Pl. Méd. Camb. Laos \& Viet. 2: 243 (1954) and 4: 21, 39, 70, 170, 184, 193, 208, \& 300. 1954; L., Hort. Cliff., 1mp. 2, 11. 1968; J. Hutchinson, Evol. \& Phylog. Flow. PI. Dicot. 470 , PIg. 474. 1969, Rimpler, Lloydia 33: 491. 1970; Saxena, Bull. Bot. Surv. India 12: 56. 1970; Scully, Treas. Am. Ind. Herbs 283. 1970; Anon., Bioresearch Ind. 7: 1061. 1971; Kachroo, Singh, \& Malik, Bull. Bot. Surv. India 13: 52. 1971; Kaul, Bull. Bot. Surv. India 13: 240. 1971; Gilmour, Thom. Johnson 31, 50, 78, 106, 107, \& 122. 1972; Healy, Gard. Guide P1. Names 37 \& 225. 1972; Frohne \& Jensen, System. Pflanzenr. 203, 261, \& 305. 1973; Hillbig, Wiss. Zeitsohr. Mart. Luth. Univ. Halle 22: 56 \& 102. 1973; Law, Conctse Herb. Encycl. 85 \& 263. 1973; El-Gazzar, Egypt. Journ. Bot. 17: 75 \& 78 . 1974; Ellenberg, Script. Geobot. 9: 80. 1974; Farnsworth, Pharmacog. T1tles 9 (4): $x_{0}$ 1974; R. D. Gibbs, Chemotax. Flow. PI. 3: 1752-1755 (1974) and L: 2295. 1974; León \& Alain, Fl. Cuba, imp. 2, 2: 281. 1974; Loewenf eld \& Back, Complete Book Herbs \& Spices 261--264. 1974; A. \& D. Löre, Cytotax. Atl. Slov. F1. 601 \& 1247. 1974; Portères, Journ. Agric. Trop. \& Bot. Appl. 21: 6. 1974; Stanley \& Linskens, Pollen 47, 95, \& 306. 1974; Sunding, Garcia de Ort. Bot. 2: 20. 1974; Täckholm, Stud. FI. Egypt, ed. 2, 454. 1974; Whitney in Foley, Herbs Use \& Delight [207]. 1974; R. \& A. Fitter, wild F18. Brit. \& N. Eu. 192, 193, \& 336. 1975; Kooiman, Act. Bot. Neerl. 24: 464. 1975; L6pez-Palacios, Revist. Fac. Farm. Univ. Los Andes 15: 88, 90, \& 93. 1975; Woberling \& Schwantes, Pflanzensyst., ed. 2 [Ulmer, Uni-Taschenb. 62:] 144. 1975; Moldenke, Phytologia 30: 156-161 (1975), 31:470 \& 412 (1975), and 34: 249, 254, 260262, 266, \& 279. 1976; Anon., Biol. Abstr. 61: ACl.732. 1976; Gal- 
Iano \& Cabezudo, Lagascal1a 6: 150. 1976; Keys, Chinese Herbs 283-284 \& 387. 1976; Lakela, Long, Fleming, \& Genelle, Pl. Tampa Bay, ed. 3 [Bot. Lab. Univ. S. Fla. Contrib. 73:] 116 \& 182. 1976; Lousley, F1. Surrey 282, map 288. 1976; Soukup, Biota 11: 19. 1976; E. H. Walker, F1. Okin, \& South. Kyuk. 883-884. 1976; Moldenke, Phytologia 36: 40, 126, 138, \& 152. 1977; A. L. Moldenke, Phytologia 36: 87. 1977 .

Additional illustrations: H. Bock [Tragus], Stirp. Max. Germ. 102. 1552; Schnitzlein, Iconogr. Fam. Nat. 2: 137 Verbenac. 1ig. 422 [partly in color] \& 30. 1856; Van Tieghem, kiém. Bot., ed. 3, 2: 373. 1898; G1lg in Engl., Syllab. Pflanzenfam., ed. 7, 314 , fig. 413 C (1912), ed. 8, 318, f1g. 413 C (1919), and ed. 9 \& 10, 339, fig. 418 C. 1924; Gunther, Herb. Apul. Barb. [16 ] . 1935; Diels in Engl., Syllab. Pflanzenfam., od. 11, 339, f1g. 432 C. 1936; Ro1, At1. P1. M\&d. Chin. [Yus. Heude Not. Bot. Chin. 8:] 96. 1946; J. Hutchinson, Evol. \& Phylog. Flow. P1. Dicot. 470, fig. 4l 4. 1969; Loewenfeld \& Back, Complete Book Herbs \& Spices [262]. 1974; R. \& A. Fitter, Wild Fls. Brit. \& N. Eu. 193, 11g. 7 (in color). 1975; Keys, Chinese Herbs 283. 1976.

Recent collectors have encountered this plant "along water channels", in irrigated wheat flelds, and "on granite substrate".

Lakela and her associates (1976) aver that in the Tampa Bay [Florlda] area V. officinalis inhabits "trails, wooded lots, [and] burns", flowering from sprint to fall, but it is most probable that the reforence here is to $\mathrm{V}$. hale1 Small.

Mrs. Clemens refers to $\nabla$. officinalis as a "common weed" in Queensland. Hendr1cks 590, c1ted below, was "purchased in market place" in Durango, Mexdco, and is questionably referred here it may, instead, actually represent the top portion of a native Mexican species.

Hutchinson (1969) regards the Verbenaceae (of which Verbena officinalis is the type species of the type gemus) as the culmination of the "fundamentaliy woody phylum, Lignosae" and therefore "at the end of the author's system" of classification of flowering plants (dicotyledons).

Sunding (1974) records V. officinalis from Santiago Island in the Cape Verde Islands, citing Sunding 2849, while Webb (1849) c1tes Hooker f. 120 from Santo Jacob1 18land. Saxena (1970) reports it as "Rare in open places" in Indis, c1ting Indorkar 1116. Kaul (1971) refers to it as an "Annual herb. Flowers pinkish white" and found it to be "rare" in Kashmir, India, flowering and fruiting there from June to August, citing Kaul $4624 \mathrm{~S}$. Strand (1756) records it from Palestine. Sonohara and his associates (1952) refer to it as "A perennial herb, common on plains; used for drugs" in Okinawa and records the common name, "kumatsuzura". Walker (1976) cites Hatusima 24199 from Yonagunl island. Lousley (1976) reports that in Surrey (England) it is "locally frequent" in "Chalk downs, quarries, waste places and roadsides, in $\mathrm{dry}$ places on chalk or gravel soils. Most common on the chalk." 
The illustration given by Loewenfeld \& Back (1974), purporting to depict $\nabla_{\text {. }}$ offlcinalis, is horribly poor and most unrepresentative of that taxon. The illustration given by Schnitzlein (1856),

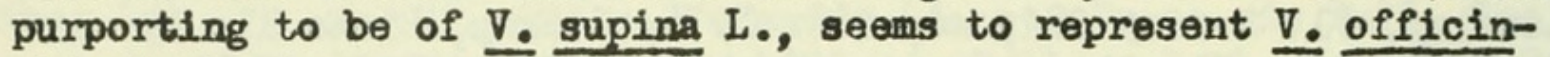
alis instead.

Friese (1933) comments that "A familia das Verbenacess conta no Estado do Espirito Santo [Brazil] uma representante nlio descripta ainda, pertencente ao genero Verbena, bem affim a especie V. officinalis L., em forma de subarbusto escandente, parcamente armado de espinhos; folhas oppostas e denteadas; inflorescencia em forma de esplga com flbres amarellas ou brancas; fruto drupaceo". This he follows with a description of the medicinal uses for the leaves, but it is most uncertain to what plant he is here referring: possibly a Lantana, but most certainly not Verbena officinalis!

Petélot (1953) affirms that $\nabla_{0}$ officinalis "Répancue dans toutes les régions tempérées et même tropicales" [in Indochina]. "C'est une plante amère legerrement tonique. Au Centre-Vletnam, 1a plante est considérés comme amère et aromatique et Loureiro.... signale qu'elle est employbe en decoction contre l'hydropisie et on cataplasmes sur les tumeurs du scrotum. D'après le $R$. $P$. Robert, elle passe pour régulariser les menstrues et pour guérir la 'boule hysterique'. Pour cela, on en prepare une purbe que l'on fait cuire et qui se prend avec de l'alcohol de $\mathrm{Mz} . "$ The Chinese name for the plant there is $n_{m a}$ pien $t s^{\prime} a{ }^{n}$, the Vietnamese name is "co rol ngyg", and in Mexico the Mayan name is "chichiantic".

Linnaeus (1737) says of this species "Crescit fuxta areas \& vias inque locis ruderatis per Belgium, Angliam, Galliam, \&c." Breyne (1739) says of it "VIRBENA valgaris follo varlegato; nobis In Horto Honestiasimae Sapientissimaeque Matronae, Domine de Flines, collegimus. Verbenae Notae: 1) Flores tubulosi, in extremo vix galeat1 \& labiat1, in caulium nec non ramorum summo, vel etian In virgulis longis e follorum sede exeuntibus spicatim ut plurimum disposit1; 2) Calix follol1s constructus; 3) Semina quaterna oblonga."

In addition to the several hundred vernacular names recorded by me in previous installments of this series of notes, Rolland (1910) lists the following: "aelius", "auricula vervicina", "ayàn nouthay", "barbàntano", "barbb́néga", "barbáno", "barbèra", "barlenn", "benerea", "beneria", "berbeana", "bérber', "bèrbèn", "berbenaca", "bèrbéno", "bèrbiłno", "bèrmàj 'no", "bèrrmèno", "biscopwurtil", "bona herba Veneris", "bonion", "bordèno", "botanica", "bouono barbéno", "brébouane", "centrum gall1", "cincinalis", "clumbeina", "columbaire", "columbaria", "columbar18", "columbina recta", "columbyne", "crfy' jeta", "crey' seta", "criféta", "crista galínacia", "crous", "dametra", "darbèno", "demedria", "demetina", "demetria", "diosatim", "diosatin", "oisebrich", "emagallis", "erba colombina", "erba de san-aíoan", "erba milzea", "erba minsaea", "erbo crousado", "erbo crusàdo", "đ̀rbo dé la mérbèlho", "èrbo dé la rato", "erbó dé lo bèrbèno". [to be continued] 


\section{$2 \mathrm{BHL}$ Biodiversity Heritage Library}

Moldenke, Harold N. 1977. "Additional notes on the genus Verbena. XXV." Phytologia 36, 216-250. https://doi.org/10.5962/bhl.part.21684.

View This Item Online: https://www.biodiversitylibrary.org/item/48956

DOI: https://doi.org/10.5962/bhl.part.21684

Permalink: https://www.biodiversitylibrary.org/partpdf/21684

\section{Holding Institution}

New York Botanical Garden, LuEsther T. Mertz Library

\section{Sponsored by}

The LuEsther T Mertz Library, the New York Botanical Garden

\section{Copyright \& Reuse}

Copyright Status: In copyright. Digitized with the permission of the rights holder.

Rights Holder: Phytologia

License: http://creativecommons.org/licenses/by-nc-sa/3.0/

Rights: https://biodiversitylibrary.org/permissions

This document was created from content at the Biodiversity Heritage Library, the world's largest open access digital library for biodiversity literature and archives. Visit BHL at https://www.biodiversitylibrary.org. 